\title{
Interactions of drought and shade effects on seedlings of four Quercus species: physiological and structural leaf responses
}

\author{
José Luis Quero ${ }^{1,2}$, Rafael Villar ${ }^{2}$, Teodoro Marañón ${ }^{3}$ and Regino Zamora ${ }^{1}$ \\ ${ }^{1}$ Grupo de Ecología Terrestre, Departamento de Ecología, Facultad de Ciencias, Universidad de Granada, E-18071 Granada, Spain; ²́rea de Ecología, Facultad \\ de Ciencias, Universidad de Córdoba, E-14071 Córdoba, Spain; ${ }^{3}$ Instituto de Recursos Naturales y Agrobiología, CSIC, PO Box 1052 , E-41080 Sevilla, Spain
}

Author for correspondence:

José Luis Quero

Tel: +34958 243242

Fax: +34958243238

Email: jlquero@ugr.es

Accepted: 6 February 2006
Received: 19 December 2005

\section{Summary}

- Here, we investigated the physiological and structural leaf responses of seedlings of two evergreen and two deciduous Quercus species, grown in a glasshouse and subjected to contrasted conditions of light (low, medium and high irradiance) and water (continuous watering vs 2 -months drought).

- The impact of drought on photosynthetic rate was strongest in high irradiance, while the impact of shade on photosynthetic rate was strongest with high water supply, contradicting the hypothesis of allocation trade-off.

- Multivariate causal models were evaluated using $d$-sep method. The model that best fitted the dataset proposed that the variation in specific leaf area affects photosynthetic rate and leaf nitrogen concentration, and this trait determines stomatal conductance, which also affects photosynthetic rate.

- Shade conditions seemed to ameliorate, or at least not aggravate, the drought impact on oak seedlings, therefore, the drought response on leaf performance depended on the light environment.

Key words: deciduous, evergreen, leaf traits, Mediterranean oaks, photosynthesis, nitrogen, specific leaf area, water-use efficiency.

New Phytologist (2006) 170: 819-834

(C) The Authors (2006). Journal compilation (c) New Phytologist (2006)

doi: 10.1111/j.1469-8137.2006.01713.x

\section{Introduction}

Light and water are main resources affecting leaf traits, regulating plant growth and survival, and determining the distribution of plants at global scale. The functional response of seedlings to the combination of shade and drought involves biochemical, physiological, and structural changes at the leaf and whole-plant level (Holmgren, 2000; Sack \& Grubb, 2002; Sack, 2004; Aranda et al., 2005). Some hypotheses predict that under limiting light availability (primary limitation), the shortage of another resource such as water should have less impact on plant performance (Canham et al., 1996). In addition, shade by the tree canopy has indirect effects, such as reducing leaf and air temperatures, vapour pressure deficit and oxidative stress, that would alleviate the drought impact on seedlings in the understorey (Holmgren, 2000). Empirical evidence of facilitation effects of shrubs and trees on seedlings in the understorey in Mediterranean environments has been widely documented (Castro et al., 2004a; Gómez-Aparicio et al., 2004). A contrary hypothesis predicts that deep shade will aggravate the stress imposed by drought, based on the proposed trade-off mechanism that shaded plants allocate more to shoot, and to leaf area, than to root, thereby diminishing the ability to capture water (Smith \& Huston, 1989). In fact, some studies have found a higher impact of water stress on shaded plants (Abrams \& Mostoller, 1995; Valladares \& Pearcy, 2002). A third group of hypotheses posits that the effects of shade and water-shortage are independent, that is, their impacts are orthogonal (Sack \& Grubb, 2002; Sack, 2004). 
In woody species, there is a suite of leaf traits associated to leaf life span. Deciduous species tend to achieve higher photosynthetic and respiration rates and higher stomatal conductance, and have higher nitrogen $(\mathrm{N})$ concentration in the leaf, compared with related evergreen species (Reich $e t$ al., 1992, 1997; Villar et al., 1995; Takashima et al., 2004; Wright et al., 2004). In Mediterranean environments, deciduous species tend to be more abundant in habitats with greater availability of water and nutrients, where the overstorey canopy is denser. Hence, it would be expected that seedlings of deciduous species are more shade-tolerant and water-demanding. By contrast, evergreen species tend to dominate in habitats that are drier and poorer in nutrients, where the overstorey canopy is sparse. We would therefore expect that seedlings of evergreen species are more tolerant to drought but not necessarily to shade.

One way to understand plants function is to explore leaf-trait relationships in different environmental conditions; however, most studies have discussed simple bivariate relationships. In order to develop a quantitative model of plant functioning relating to gas exchange, it would be necessary to move to multivariate relationships to be investigated by causal model (Meziane \& Shipley, 2001). These authors proposed a model in which SLA was the forcing variable directly affecting both leaf $\mathrm{N}$ and net photosynthetic rate. Leaf $\mathrm{N}$ then directly affects photosynthetic rate, which in turn affects stomatal conductance. This model was found to agree with several datasets (Meziane \& Shipley, 2001). To date, these models have not been applied to datasets with limiting light and water conditions, as are typical of Mediterranean forest.

We have designed an experiment with controlled conditions of light and water to investigate the physiological and structural leaf traits responses of tree seedlings to six combinations of light (three levels) and water (two levels). Four species of the same genus (Quercus) differing in leaf life span, were selected: two evergreens and two deciduous. Thus, we compared deciduous and evergreen species under the same genus, including the phylogeny in the design and data analysis.
There are some specific questions to investigate plant responses to different light-water scenarios: Are shade and drought impacts on seedlings positive, negative or independent? Do species or functional groups (evergreen vs deciduous) respond differently? Which physiological and structural leaf traits are most affected by the combined stress? What are the functional relationships among those variables? The answers to these questions would help to understand the functioning of plants and their implications for the species distribution in nature.

\section{Materials and Methods}

\section{Experimental design}

Acorns of four oak species, major components of Mediterranean forest - Quercus suber L., Quercus ilexssp. ballota (Desf.) Samp. (evergreen), Quercus canariensis Willd. and Quercus pyrenaica Willd. (deciduous) - were collected in the south of Spain. At landscape scale, the evergreen species tend to occupy drier habitats than the deciduous species at each site, although the regional ranges overlap (see Table 1 for more details). Single acorns were weighted individually and sown (in December 2002) in cylindrical pots of $3.9-1$ volume $(50 \mathrm{~cm} \mathrm{high} \times 10 \mathrm{~cm}$ diameter), thereby avoiding as much as possible interference during root growth. Pots contained a mixed soil of $2: 3$ sand and $1: 3$ peat. Ten grams of a slow-release fertilizer (Plantacote, Pluss NPK: $14: 9: 15$, Aglukon, Valencia, Spain) were added at the middle of the experiment. The experiment was carried out in a glasshouse of the University of Córdoba (Spain, $37^{\circ} 51^{\prime} \mathrm{N}, 4^{\circ} 48^{\prime} \mathrm{W}$; at an altitude of $100 \mathrm{~m}$ ) with an automatic irrigation system and regulation of air temperature.

Oak seedlings were subjected to three light levels: (1) highirradiance treatment $(\mathrm{HI})$, receiving available radiation inside the glasshouse; (2) medium-irradiance treatment (MI), covered by a light-green screen ( $27 \%$ of available radiation); and (3) deep-shade or low-irradiance treatment (LI), covered by a dense green cloth (3\% of available radiation). Each light treatment was imposed using a shade frame $(150 \times 120 \times 200 \mathrm{~cm})$ and

Table 1 Oak species included in the experiment (nomenclature follows Amaral, 1990), their leaf life span, frequency in southern Spain (calculated from 12572 records in the National Forest Inventory) and range of precipitation where they were recorded

\begin{tabular}{|c|c|c|c|c|c|}
\hline \multirow[b]{2}{*}{ Species } & \multirow[b]{2}{*}{ Origin of seeds } & \multirow{2}{*}{$\begin{array}{l}\text { Functional } \\
\text { group }\end{array}$} & \multirow{2}{*}{$\begin{array}{l}\text { Frequency in } \\
\text { southern Spain (\%) }\end{array}$} & \multicolumn{2}{|c|}{ Precipitation (mm) } \\
\hline & & & & Mean & Range \\
\hline Quercus canariensis Willd. & $\begin{array}{l}\text { Sierra del Aljibe } \\
\text { (SE Spain) }\end{array}$ & Deciduous & 2.4 & 1073 & $628-1338$ \\
\hline Quercus ilex ssp. ballota (Desf.) Samp & $\begin{array}{l}\text { Sierra Nevada } \\
\text { (SW Spain) }\end{array}$ & Evergreen & 50.8 & 668 & $268-1366$ \\
\hline Quercus pyrenaica Willd. & $\begin{array}{l}\text { Sierra de Cardeña } \\
\text { (S Spain) }\end{array}$ & Deciduous & 0.4 & 773 & $604-990$ \\
\hline Quercus suber L. & $\begin{array}{l}\text { Sierra del Aljibe } \\
\text { (SE Spain) }\end{array}$ & Evergreen & 15.8 & 839 & $489-1366$ \\
\hline
\end{tabular}

Data from the National Meteorological Institute; Urbieta et al. (2004). 
Table 2 (a) Soil water content (measured with TDR) at the beginning, middle and end of the experiment (mean \pm SE) in a subsample of pots under the six light and water combinations; (b) results of the three-way ANOVA for the effects of water supply (W), irradiance treatments (I), and species (S), and their interactions at the end of the experiment for all pots where photosynthetic measurements were done

\begin{tabular}{|c|c|c|c|c|c|c|c|}
\hline & \multirow[b]{3}{*}{ Time (d) } & \multicolumn{6}{|c|}{ Combined treatments } \\
\hline & & \multicolumn{3}{|l|}{ High water } & \multicolumn{3}{|l|}{ Low water } \\
\hline & & $\mathrm{LI}$ & $\mathrm{MI}$ & $\mathrm{HI}$ & $\mathrm{LI}$ & $\mathrm{Ml}$ & $\mathrm{HI}$ \\
\hline \multicolumn{8}{|l|}{ (a) } \\
\hline \multirow[t]{3}{*}{ Soil water content (\%) } & 0 & $13.8 \pm 0.6$ & $12.4 \pm 0.6$ & $12.0 \pm 0.6$ & $13.1 \pm 0.6$ & $10.3 \pm 0.6$ & $11.1 \pm 0.6$ \\
\hline & 30 & $11.8 \pm 0.5$ & $11.0 \pm 0.5$ & $11.0 \pm 0.5$ & $6.6 \pm 0.5$ & $5.2 \pm 0.5$ & $3.6 \pm 0.5$ \\
\hline & 60 & $12.8 \pm 0.4$ & $13.2 \pm 0.4$ & $13.2 \pm 0.4$ & $3.2 \pm 0.4$ & $2.4 \pm 0.1$ & $2.2 \pm 0.1$ \\
\hline \multicolumn{8}{|l|}{ (b) } \\
\hline \multirow[t]{9}{*}{ 3-way ANOVA results } & Factor & $d f$ & Mean squares & $P$ & & & \\
\hline & Water (W) & 1 & 3053 & $<0.001$ & & & \\
\hline & Irradiance (I) & 2 & 69.02 & 0.408 & & & \\
\hline & Species (S) & 3 & 66.14 & 0.461 & & & \\
\hline & $W \times 1$ & 2 & 16.70 & 0.804 & & & \\
\hline & $\mathrm{W} \times \mathrm{S}$ & 3 & 6.98 & 0.965 & & & \\
\hline & $\mathrm{I} \times \mathrm{S}$ & 6 & 32.96 & 0.856 & & & \\
\hline & $\mathrm{I} \times \mathrm{W} \times \mathrm{S}$ & 6 & 7.63 & 0.996 & & & \\
\hline & Error & 111 & 76.38 & & & & \\
\hline
\end{tabular}

$\mathrm{HI}$, high irradiance; MI, medium irradiance; LI, low irradiance (see the Materials and Methods section for details).

replicated four times; therefore, there were 12 shade frames in total. Each of the four species and the two levels of watering were set up within each shade frame, each by one plant in a single pot. The experimental light treatments simulated the field conditions in the forest understorey, distinguishing three types of microhabitat: open (HI), under single tree cover (MI), and under shrub and tree cover (LI) (Marañón et al., 2004). The mean \pm SE of the photosynthetic active radiation measured (with EMS7, canopy transmission meter, PP-system, UK) at midday on May 28, 2003, for each light treatment was $760 \pm$ $150,187 \pm 27$ and $23 \pm 2 \mu \mathrm{mol}$ of photons $\mathrm{m}^{-2} \mathrm{~s}^{-1}$ in HI, MI and LI respectively. Light quality (red:far red (R : FR) ratio, measured with sensor SKR 110; Skye Instruments, Llandrindod Wells, UK) was different from 1 only in LI, but this value $(0.25 \pm 0.004)$ was similar to that for dense forest microhabitat $(0.28 \pm 0.03$, $t$-test, $P=0.31)$.

Pots were watered weekly during the first stage of the experiment. Once the seedlings emerged (January-February, 2003), a drip-irrigation system was inserted in the pots. Four months after sowing (at the end of April 2003), half of the pots stopped receiving any watering (low-water treatment, LW) while the other half was kept continuously moist (highwater treatment, HW). Low-water treatment simulated a typical Mediterranean-climate situation of seasonal drought, compared with a continuously moist one (HW) with reduced or no drought. During the experiment, we measured soil moisture (in volumetric water content, VWC), measured along the first $20 \mathrm{~cm}$ depth (with a TDR mod 100; Spectrum Technologies, Inc., Plainfield, IL, USA) each c. 3 d, in a subsample of five pots under different light and water treatments. Pots under LW decrease their water content similarly for the three light treatments (Table $2 \mathrm{a}$; repeated measures ANOvA, $P=0.17$ ). At the same time of photosynthetic measurements (end of July 2003, c. 2 months after stopping irrigation), we measured VWC of each pot. For each water treatment, there were no differences in water content between the pots of different species or between the three different light treatments at the end of the experiment (Table $2 b$ ). The mean \pm SE values in July 2003, were $13.20 \pm 0.20 \%$ (for HW treatment) and $2.96 \pm 0.13 \%$ (for LW). The latter value was very similar to those found under field conditions at the end of the drought period (Gómez-Aparicio et al., 2005).

\section{Physiological and structural measurements}

Photosynthesis response to irradiance was measured in midheight fully expanded leaf of, in general, six plants per species and treatment combination. The measurements were done in the four different shade frames (replicates) for each light treatment to avoid pseudoreplication. We used a gas-exchange portable analyser (Ciras-2; PP-System, Hitchin, UK). The instrument was adjusted to have constant conditions of $\mathrm{CO}_{2}$ concentration (360 p.p.m), flow $\left(150 \mathrm{~cm}^{3} \mathrm{~min}^{-1}\right)$, and leaf temperature $\left(25^{\circ} \mathrm{C}\right)$ inside the leaf chamber. Photosynthetic rate was measured at 10 light intensities of PAR obtained by using a quartz halogen light unit coupled to leaf chamber following the order 1000, 1300, 1500, 800, 600, 400, 200, 100,50 and $0 \mu \mathrm{mol} \mathrm{m} \mathrm{m}^{-1}$ (Fig. 1), to reduce the equilibrium time required for stomatal opening and photosynthesis induction (Kubiske \& Pregitzer, 1996). Each leaf was kept for 1 min at the same light intensity into the leaf chamber; net assimilation rate, transpiration rate and intercellular $\mathrm{CO}_{2}$ concentration 

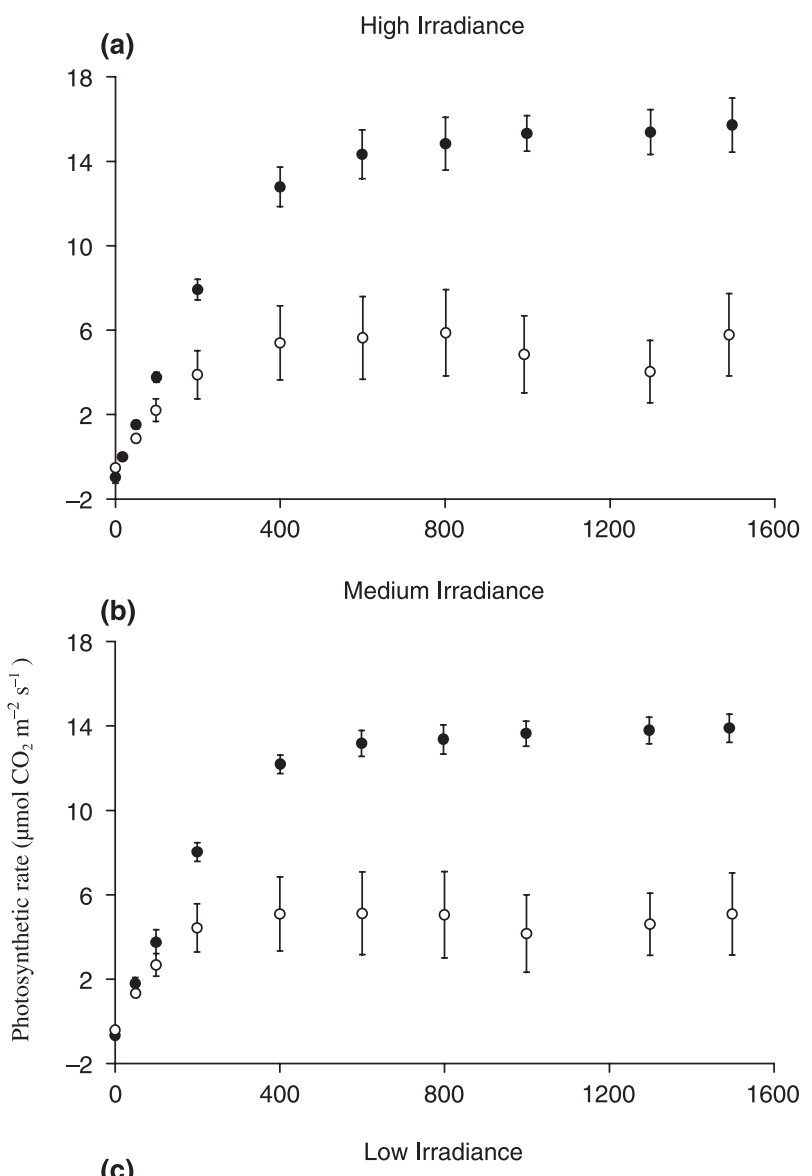

(c)

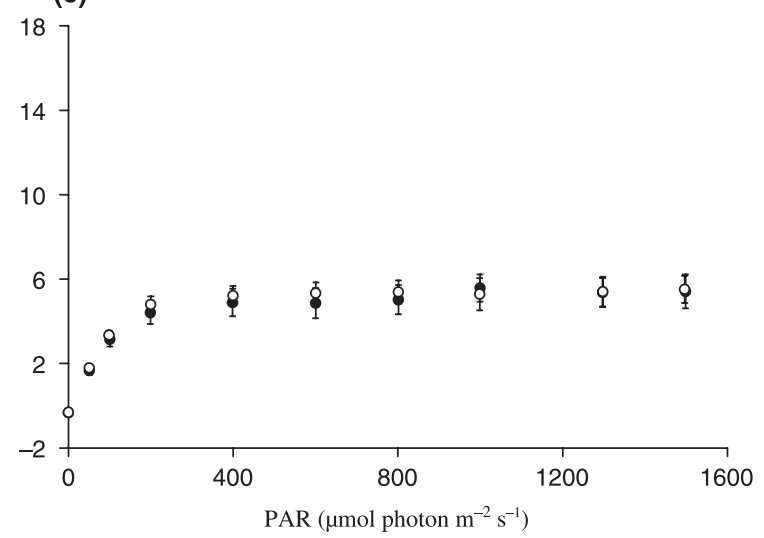

Fig. 1 Evolution of the photosynthetic rate (mean values and SE bars) with increasing irradiance (light curves), for seedlings (e.g. Quercus pyrenaica) cultivated in high $(100 \%, a)$, medium $(27 \%, b)$, and low $(3 \%, c)$ irradiance, respectively. In each Figure (of light conditions), seedlings under continuous irrigation treatment (closed circles, high water treatment) are distinguished from seedlings subjected to drought (open circles, low water treatment).

were recorded three times, and the average value at each light intensity was calculated. $\mathrm{Net} \mathrm{CO}_{2}$ assimilation rates (A) were plotted against incident PAR, and the resulting curve was fitted by the nonrectangular hyperbola model of Thornley (1976):

$$
A(I)=\frac{\sqrt{\left(\Phi I+A_{\max }\right)^{2}-4 \theta I A_{\max }}}{2 \theta}-R_{d}
$$

( $A$, photosynthetic rate; $I$, photosynthetic active radiation (PAR); $\Phi$, apparent quantum yield; $A_{\max }$, maximum light saturated assimilation rate; $R_{d}$, dark respiration rate; $\theta$, 'bending degree' or curvature). Parameters of the model were calculated by the nonlinear estimation module (STATISTICA version 6.0, Statsoft, Inc., Tulsa, OK, USA). The variance explained by the model was very high (mean $r^{2}$ values of $0.98 \pm 0.03$ ). Despite its methodological importance, this value is rarely given, and comparison with other studies is difficult. Using this formula, by definition, the maximum photosynthetic rate is obtained at the infinite light intensity, and then overestimated. Therefore, we recalculated $A_{\max }$ (hereafter, $\mathrm{A}_{\text {area }}$ ) assuming a PAR of $2000 \mu \mathrm{mol} \mathrm{m}^{-2} \mathrm{~s}^{-1}$, the approximate maximum value for that season and latitude (Castro et al., 2004b; Rey-Benayas et al., 2005). The light saturation point (LSP) was calculated as the lowest value of PAR for which photosynthesis reached $90 \%$ of $A_{\text {area: }}$. Water-use efficiency (WUE) values were calculated as $\mathrm{A}_{\text {area }}$ : stomatal conductance per area $\left(\mathrm{gs}_{\text {area }}\right)$ ratio (Cavender-Bares \& Bazzaz, 2000) and photosynthetic $\mathrm{N}$-use efficiency (PNUE) as photosynthetic rate per mass $\left(\mathrm{A}_{\text {mass }}\right) / \mathrm{N}$ concentration (Field \& Mooney, 1986).

In the same leaves, a chlorophyll index was measured using a CCM-200 (Optic Science, Hudson, NH, USA), which works similarly to SPAD (Minolta) and readings are well correlated with chlorophyll content. Leaves were then collected and scanned, and the area was measured with an image analyser (IMAGE PRO-Plus version 4.5; Media Cybernetic, Inc., Silver Spring, MD, USA). They were oven-dried (at $80^{\circ} \mathrm{C}$ for at least $48 \mathrm{~h}$ ) and weighed. The specific leaf area (SLA) was calculated as the ratio between the leaf area and its dry mass. Leaves were ground with liquid $\mathrm{N}$ in an agate mortar, and analysed for $\mathrm{N}$ and carbon $(\mathrm{C})$ concentration using an elemental analyser (Eurovector EA 3000; EuroVector SpA, Milan, Italy).

The level of response to the variation of each factor (light and water) was estimated by the indices Response $e_{\text {light }}$ and Response $_{\text {water }}$, respectively, ranging from 0 to 1 . The index of response was calculated as the difference between the maximum and the minimum mean values, divided by the maximum mean value. Although other authors called this the plasticity index (PI) (Valladares et al., 2000a), we have preferred the neutral term 'Response' first, because in the case of water treatment, the seedlings had to adjust to a seasonal drought and were not acclimatized from the beginning of the experiment, and second, because we did not control possible genetic variability.

\section{Statistical analyses}

Mean $( \pm$ SE) values of the 20 variables of seedling leaf performance, for each Quercus species and irradiance and water treatment, are shown in Appendix 1. To avoid pseudoreplication, we calculate the mean values of the different variables for each light treatment replicates. These mean values were used to test 
the differences among species and the effects of light and water treatments on each variable by three-way ANOVAs (species, light, and water as source factors) with Type III sums of squares. Previously, ANCOVA was explored considering the seed mass as covariable; seed mass did not significantly affect leaf traits of 6-month-old seedlings ( $P>0.05$ in all cases); therefore, we present here only the ANOVA results for simplicity. A similar ANOVA procedure was used to explore the differences between deciduous and evergreen species, using leaf habit as factor instead of species. When the difference was significant, a multiple comparison of means test (post hoc Unequal NTukey's Honestly Significant Difference test) was carried out. Before ANCOVA and ANOVA, data were square-root-, arcsine-, or log-transformed to satisfy the normality and homoscedasticity assumptions (Zar, 1984). Leaf-trait relationships were studied by Pearson's correlation analyses between pairs of variables, separating watered and drought conditions. The program STATISTICA version 6.0 (Statsoft, Inc., Tulsa, OK, USA) was used for statistical analyses.

In order to explain the empirical patterns of direct and indirect covariation between variables, a multivariate analysis was carried out to test for causal models linking changes in main leaf traits (SLA and N content) with physiological performance (photosynthetic rate and stomatal conductance), following Shipley's d-sep method (Shipley, 2000). Significance was fixed at the 0.05 level throughout the study. In order to control the inflation of type I error derived from repeated testing, the false discovery rate (FDR, the expected proportion of tests erroneously declared as significant) criterion was applied to repeated test tables throughout the paper. The FDR was controlled at the $5 \%$ level using a standard step-up procedure (see García, 2004). However, when testing multiple path models, we obtained an estimate for the expected number of erroneously accepted null hypotheses (type II errors), while controlling the FDR at the 5\% level (Ventura et al., 2004). This approach allowed us to focus the attention on those accepted models which had a low probability of being type II errors.

\section{Results}

\section{Combined effects of shade and drought}

The reduction in the availability of light and water imposed structural changes in the leaves of oak seedlings and affected their physiological performance (Figs 1 and 2).

Most variables showed strong interactions of light and water effects (as demonstrated by the ANOVAs, Table 3 and Fig. 2), reflecting that the drought impact on the physiological and structural traits of seedlings was highly significant under $\mathrm{HI}$ and MI but negligible under LI. Some exceptions were SLA and $\mathrm{N}$ concentration (Fig. 2).

Photosynthetic rate and stomatal conductance of the four oak species were similar along the three irradiance levels in HW (Fig. 2a,b). However, these traits decreased with irradiance under the LW. WUE (ratio between these traits) showed differences in water treatments, being higher in LW. However, PNUE decreased in LW as whole (Table 3).

Leaves of oak seedlings grown under LI had higher SLA (Fig. 2c) and were richer in N (Fig. 2d).

\section{Differences among Quercus species}

Leaf structural traits were characteristic of each species and showed significant differences in the ANOVAs (see species as factor in Table 3; Appendix 1). For example, leaf area varied across the species (54\% of variance explained) and SLA showed statistical differences among each of the four Quercus species (30\% of variance), with the rank Q. ilex $<$ Q. suber $<$ Q. pyrenaica $<$ Q. canariensis (Fig. 2C).

Fewer physiological features varied across the Quercus species (only 6 out of 13; Table 3). For example, $A_{\text {mass }}$ differed among species (22\% of variance; deciduous Q. pyrenaica and $Q$. canariensis had higher values than evergreen $Q$. ilex and $Q$. suber) (Fig. 2a). In general, the effects of shade and/or drought on physiological variables were higher than the interspecific variation (for example, LCP was highly affected by light (38\% of variance), but varied only slightly across species ( $1 \%$ of variance)) (Table 3).

\section{Differences between functional groups}

Leaf traits of seedlings were related to the leaf habit. When the seedlings of deciduous species ( $Q$. pyrenaica and $Q$. canariensis) were grouped and compared by ANOVAs with the evergreen species ( $Q$. ilex and $Q$. suber), all seven leaf structural traits showed significant differences (Appendix 1). Seedlings of deciduous species had higher leaf area, SLA (Fig. 2c), and N concentration ( $\mathrm{N}_{\text {mass }}$, Fig. $\left.2 \mathrm{~d}\right)$, but lower chlorophyll (Chl) index (Appendix 1).

Differences in life span also predicted some variation in seedling physiological performance (significant ANOVAs for 5 out of 13 variables). Seedlings of deciduous species had higher $A_{\text {mass }}\left(19 \%\right.$ of variance), respiration rate per mass $\left(R_{\text {mass }}\right)(13 \%$ of variance), PNUE (13\% of variance), and stomatal conductance (3\% of variance) than evergreens. There were no apparent differences between deciduous and evergreen seedlings in WUE.

\section{Responses to variation of light and water}

There was a high variation in the degree of response to light vs that to water, for the 20 variables measured (Fig. 3). Results for the four species were averaged to show the general response pattern. The response to light $\left(\right.$ Response $\left._{\text {light }}\right)$ had a mean value of about 0.35 for the 20 variables, with a wide variation among them (Fig. 3). The structural water-induced response of leaf traits was very low (mean Response ${ }_{\text {water }}$ of 0.07 ), while the general physiological response was relatively high (mean Response $_{\text {water }}$ of 0.35) (Fig. 3). Some variables had relatively persistent values even for stressed seedlings (low response traits). 
Evergreens
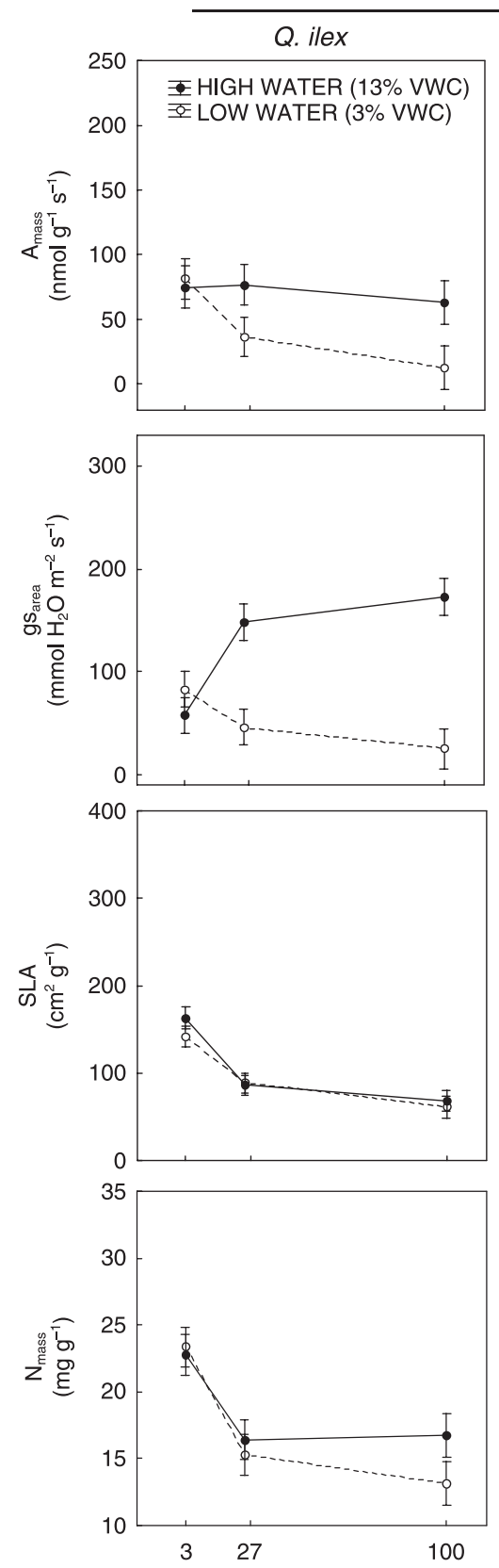

Q. suber
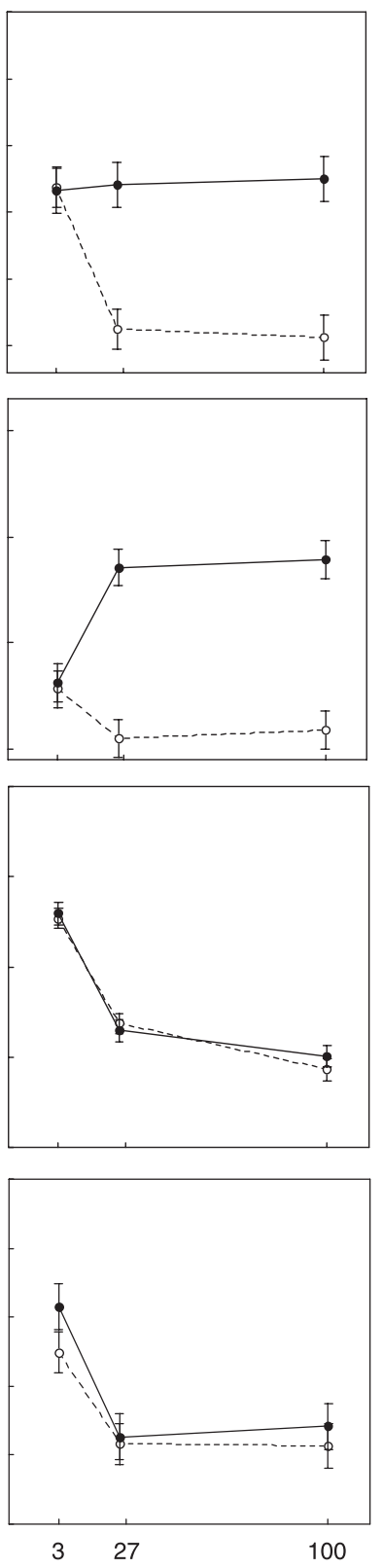

Deciduous
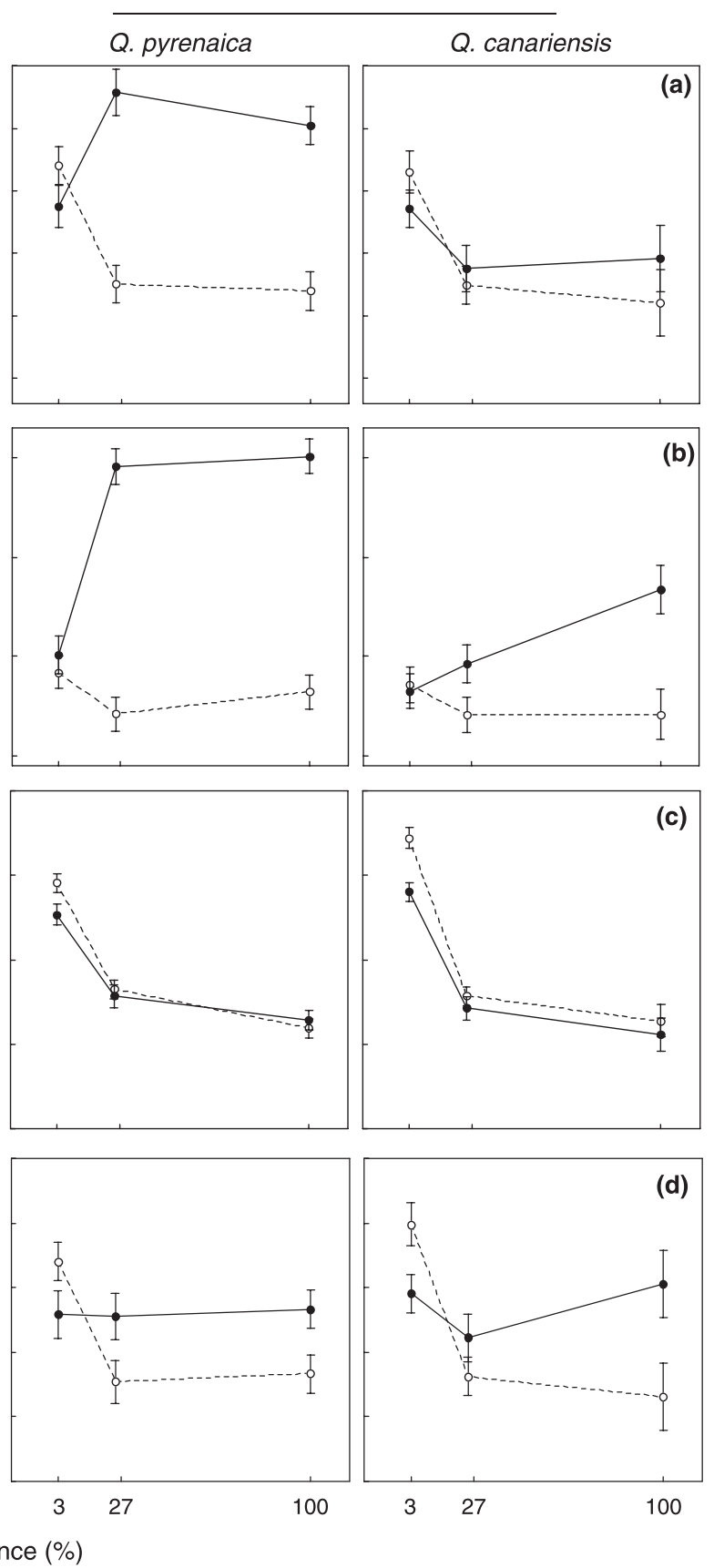

Fig. 2 General variation in leaf traits of oak seedlings (means and SE bars for replicates of the four Quercus species) in response to the six combinations of light and water treatments. Light levels are 'Low irradiance' (LI, 3\%), 'Moderate irradiance' (MI, 27\%), and 'High irradiance' (HI, $100 \%)$, and water levels are 'High water' ( $\mathrm{HW}$, solid line) and 'Low water' ( $\mathrm{LW}$, dashed line). a) $\mathrm{A}_{\text {mass' }}$ photosynthetic rate per mass $\left(\mathrm{nmol}^{\mathrm{CO}} \mathrm{C}_{2} \mathrm{~g}^{-1} \mathrm{~s}^{-1}\right)$; b) $\mathrm{gs}_{\text {area' }}$ stomatal conductance per mass $\left(\mathrm{mmol} \mathrm{H}_{2} \mathrm{O} \mathrm{m}^{-2} \mathrm{~s}^{-1}\right)$; c) SLA, specific leaf area $\left(\mathrm{cm}^{2} \mathrm{~g}^{-1}\right)$; d) $\mathrm{N}_{\text {mass' }}$ nitrogen concentration $\left(\mathrm{mg} \mathrm{g}^{-1}\right)$.

Among the variables exhibiting high response, some were highly affected by shade (Response light $>0.5)$ but not affected by drought; the most remarkable example is SLA. By contrast, other leaf traits had high response in drought-affected seedlings (Response $_{\text {water }}>0.5$ ), but were more independent of shade stress; the best example here is the gs $s_{\text {area }}$ and $\mathrm{A}_{\text {area }}$.
Causal links among leaf structural traits and physiological performance

A diverse correlation patterns were revealed among leaf structural traits and physiological variables. These relationship patterns were similar for the four oak species between different variables 
Table 3 Results of the three-way ANOVAS for some structural and physiological leaf traits, according to the factors oak species (S), and light (L) and water $(\mathrm{W})$ treatments

\begin{tabular}{|c|c|c|c|c|c|c|c|c|}
\hline \multirow[b]{2}{*}{ Leaf traits } & \multirow[b]{2}{*}{ Species } & \multicolumn{2}{|l|}{ Factors } & \multicolumn{4}{|c|}{ Interactions } & \multirow[b]{2}{*}{$R^{2}$} \\
\hline & & Light & Water & $\mathrm{L} \times \mathrm{W}$ & $\mathrm{S} \times \mathrm{L}$ & $\mathrm{S} \times \mathrm{W}$ & $S \times L \times W$ & \\
\hline \multicolumn{9}{|c|}{ Structural traits } \\
\hline Area & $53.8 * * *$ & $12.1^{* * *}$ & 0.0 & 1.3 & 2.1 & 1.4 & 2.0 & 72.8 \\
\hline SLA & $29.9 * * *$ & $63.7^{* * *}$ & 0.0 & 0.1 & 0.8 & 0.4 & 0.5 & 95.3 \\
\hline $\mathrm{N}_{\text {mass }}$ & $14.5^{* * *}$ & $39.8 * * *$ & $5.5^{* * *}$ & $4.9 * *$ & 3.5 & 0.4 & 5.3 & 73.9 \\
\hline$C_{\text {mass }}^{\text {mass }}$ & $50.8 * * *$ & 1.0 & $\underline{2.8}^{*}$ & 0.3 & 3.4 & $6.0^{*}$ & 2.2 & 66.5 \\
\hline $\mathrm{N}_{\text {area }}$ & $29.0 * * *$ & $44.4^{* * *}$ & $3.5 * *$ & $1.8^{*}$ & 2.1 & 1.7 & 2.2 & 84.6 \\
\hline $\mathrm{C}_{\text {area }}^{\text {dred }}$ & $34.1 * * *$ & $59.2 * * *$ & 0.0 & $\overline{0.1}$ & 0.9 & 0.6 & 0.4 & 95.3 \\
\hline Chl index & $31.9 * * *$ & $5.2^{*}$ & $6.7 * *$ & $6.5^{* *}$ & 3.4 & 4.3 & 4.4 & 62.5 \\
\hline \multicolumn{9}{|c|}{ Physiological traits } \\
\hline$\Phi$ & 3.2 & $7.5^{*}$ & $19.6^{* * *}$ & $7.3^{*}$ & 4.7 & 2.3 & 5.9 & 50.5 \\
\hline$\theta$ & 4.9 & $6.6^{*}$ & 1.6 & $9.3^{* *}$ & $14.4^{*}$ & 4.4 & 9.1 & 50.3 \\
\hline LCP & 0.9 & $38.2 * * *$ & 0.2 & $5.4^{*}$ & 2.7 & $7.7^{*}$ & 5.4 & 60.5 \\
\hline LSP & 0.3 & $18.1 * * *$ & $10.1 * * *$ & $6.4^{*}$ & 9.1 & 4.2 & 5.2 & 53.5 \\
\hline$A_{\text {area }}$ & $5.8^{* * *}$ & $5.9^{* * *}$ & $37.0^{* * *}$ & $23.4^{* * *}$ & 2.3 & $4.0^{* *}$ & 2.3 & 80.7 \\
\hline $\mathrm{R}_{\text {area }}$ & 3.2 & $18.2^{* * *}$ & $16.7^{* * *}$ & 0.2 & 5.7 & 3.0 & 5.4 & 47.5 \\
\hline gs area & $7.4^{* * *}$ & $2.0^{*}$ & $46.0 * * *$ & $24.2^{* * *}$ & 0.5 & $3.3 * *$ & 1.6 & 84.8 \\
\hline$A_{\text {mass }}$ & $21.9 * * *$ & $14.2 * * *$ & $21.5^{* * *}$ & $14.4^{* * *}$ & 1.9 & $5.0^{* *}$ & 2.9 & 81.7 \\
\hline$R_{\text {mass }}^{\text {mass }}$ & $17.9 * * *$ & 3.4 & $12.5^{* * *}$ & 0.7 & 5.6 & 3.5 & 5.0 & 48.6 \\
\hline gs mass & $19.2^{* * *}$ & $7.8^{* * *}$ & $30.8^{* * *}$ & $15.6^{* * *}$ & 0.2 & $4.6^{* *}$ & $2.1^{*}$ & 80.3 \\
\hline WUE & 2.4 & 3.0 & $19.9 * * *$ & $12.6 * * *$ & 7.8 & $8.6^{* *}$ & 5.6 & 59.9 \\
\hline PNUE & $17.5^{* * *}$ & $6.1^{* *}$ & $24.1^{* * *}$ & $13.7^{* * *}$ & 1.5 & $7.6 * * *$ & $6.0^{*}$ & 76.6 \\
\hline $\mathrm{Ci} / \mathrm{Ca}$ & 2.1 & $\underline{5.1}^{*}$ & $9.0 * * *$ & $10.7^{* *}$ & $13.5^{* * *}$ & $9.0^{* * *}$ & $\overline{6.3}$ & 55.7 \\
\hline
\end{tabular}

The proportion of the explained variance (SS $/$ SStotal) and the level of significance $\left({ }^{*}, P<0.05 ;{ }^{*}, P<0.01 ; * * *, P<0.001\right)$ for each factor and the interactions are indicated; those values not remaining significant after controlling the false discovery rate are underlined. $R^{2}$ is the proportion of total variance absorbed by the model. $\Phi$, quantum yield (no units); $\theta$, curvature (no units); Area, leaf area $\left(\mathrm{cm}^{2}\right) ; A_{\text {area' }}$ photosynthetic rate per area $\left(\mu \mathrm{mol} \mathrm{CO} \mathrm{CO}_{2} \mathrm{~m}^{-1}\right) ; A_{\text {mass }}$ photosynthetic rate per mass $\left(\mathrm{nmol} \mathrm{CO} \mathrm{CO}^{-1} \mathrm{~s}^{-1}\right) ; \mathrm{C}_{\text {area' }}$ carbon content per area $\left(\mathrm{g} \mathrm{C} \mathrm{m}{ }^{-2}\right) ; \mathrm{C}_{\text {mass' }}$ carbon concentration ( $\mathrm{mg} \mathrm{g}^{-1}$ ); $\mathrm{Chl}$ index, chlorophyll index (no units); $\mathrm{Ci} / \mathrm{Ca}$, ratio internal vs external $\mathrm{CO}_{2}$ concentration; gs area' stomatal conductance per area $\left(\mathrm{mmol} \mathrm{H}_{2} \mathrm{O} \mathrm{m}^{-2} \mathrm{~s}^{-1}\right)$; gs mass, stomatal conductance per mass $\left(\mathrm{mmol} \mathrm{H}_{2} \mathrm{O} \mathrm{g} \mathrm{g}^{-1} \mathrm{~s}^{-1}\right)$; LCP, light compensation point ( $\mu$ mol photons $\left.\mathrm{m}^{-2} \mathrm{~s}^{-1}\right)$; LSP, light saturation point ( $\mu \mathrm{mol}$ photons $\left.\mathrm{m}^{-2} \mathrm{~s}^{-1}\right) ; \mathrm{N}_{\text {area' }}$, nitrogen content per area $\left(\mathrm{g} \mathrm{N} \mathrm{m}^{-2}\right) ; \mathrm{N}_{\text {mass' }}$, nitrogen concentration $\left(\mathrm{mg} \mathrm{g}^{-1}\right) ; \mathrm{R}_{\text {arear }}$ respiration rate per area $\left(\mu \mathrm{mol} \mathrm{CO} \mathrm{Cm}^{-2} \mathrm{~s}^{-1}\right) ; \mathrm{R}_{\text {mass }}$, respiration rate per mass $\left(\mathrm{nmol} \mathrm{CO} \mathrm{g}^{-1} \mathrm{~s}^{-1}\right)$; PNUE, photosynthetic nitrogen-use efficiency $\left(\mu \mathrm{mol} \mathrm{CO} 2(\mathrm{~mol} \mathrm{~N})^{-1} \mathrm{~s}^{-1}\right)$; SLA, specific leaf area $\left(\mathrm{cm}^{2} \mathrm{~g}^{-1}\right)$; WUE, water-use efficiency $\left(\mu \mathrm{mol} \mathrm{CO} 2\left(\mathrm{mmol} \mathrm{H}_{2} \mathrm{O}\right)^{-1}\right)$.

shown in the four oak species (test of Homogeneity of slopes model, $P>0.05$ for all cases; data not shown). In many cases, correlations between leaf traits differed depending on the water treatment (44\% of bivariate relationships were different, Table 4). $A_{\text {mass }}$ and $R_{\text {mass }}$ were significantly correlated in both drought and watered conditions (Table 4). $A_{\text {mass }}$ was also correlated

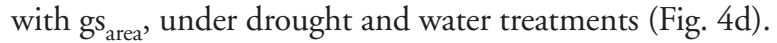

In some cases, leaf structural traits can be used as predictors of physiological performance. $\mathrm{N}_{\text {mass }}$ was a good predictor of $\mathrm{gs}_{\text {area; }}$; but only for drought-affected seedlings (Fig. 4c). The specific leaf area (SLA) was a good predictor for several physiological activities. Seedlings of higher SLA tended to have higher photosynthetic rate (Fig. 4B), higher $\mathrm{N}_{\text {mass }}$ (Fig. 4a), and lower LCP and LSP (Table 4). The instantaneous water-use efficiency (WUE) was negatively correlated with the instantaneous photosynthetic N-use efficiency (PNUE) for watered seedlings, but not when affected by drought (Table 4). The SLA of drought-affected seedlings (unlike watered ones) was significantly correlated with PNUE. The WUE was not correlated with SLA for either of the water treatments.
The results of the multivariate analyses (d-sep test) of causal models linking leaf traits (SLA and $\mathrm{N}_{\text {mass }}$ ) and physiological functions $\left(\mathrm{A}_{\text {mass }}\right.$ and gs $\left.{ }_{\text {mass }}\right)$ are shown in Table 5 and Fig. 5. Model D was accepted by the whole dataset and most of the different light and water treatments. According to this model, the variation in SLA affects $A_{\text {mass }}$ and $\mathrm{N}_{\text {mass }}$, and this trait determines gs mass , which also affects photosynthetic rate. Model F, which best fitted the datasets in the study by Meziane \& Shipley (2001), was also accepted by most datasets in this experiment but did not fit the data of LI, and hence it was rejected for the combined dataset (Table 5).

\section{Discussion}

Are the impacts of shade and drought on seedlings, positive, negative or independent?

Most leaf traits showed strong interactions in their responses to light and water treatments (Table 3; Fig. 2), and hence their variation was not independent. We did find that oak seedlings 


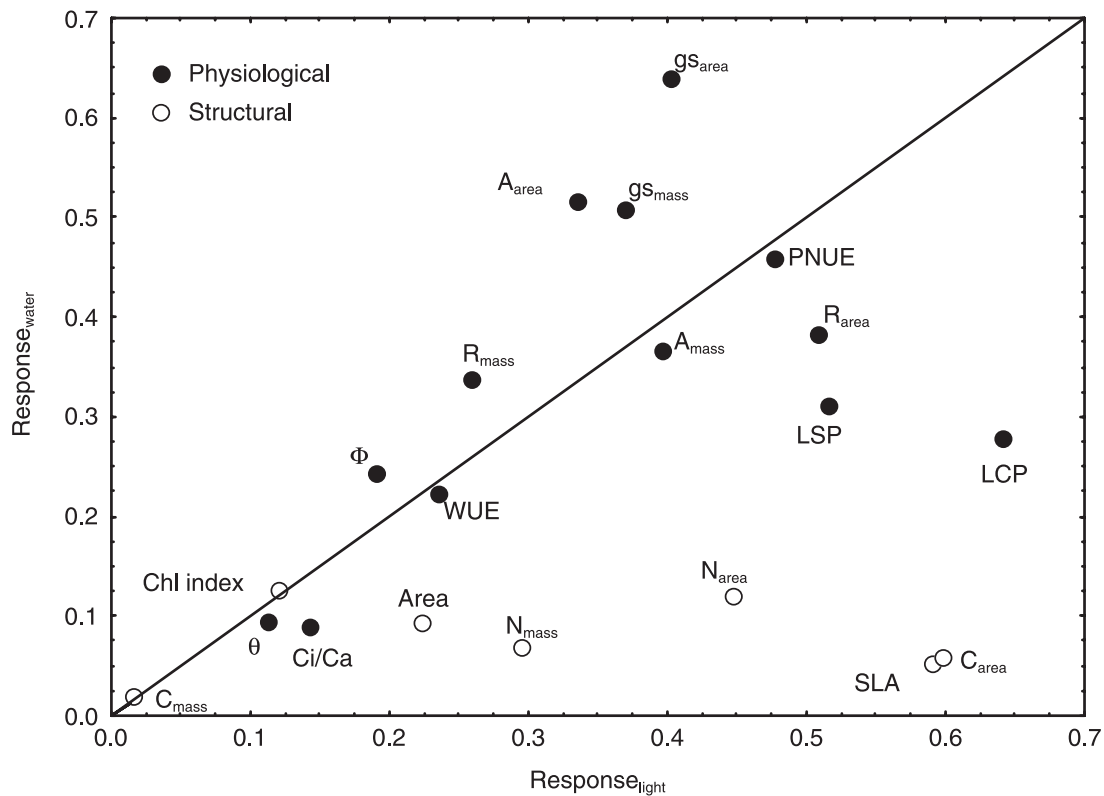

Fig. 3 Bivariate diagram of the comparative response to light (Response light $_{\text {) }}$ vs the response to water (Response water $_{\text {) }}$, for physiological and structural leaf traits, averaged for the four oak species. Response was calculated as (maximum value - minimum value/maximum value). $\Phi$, quantum yield (no units); $\theta$, curvature (no units); Area, leaf area $\left(\mathrm{cm}^{2}\right) ; A_{\text {arear }}$, photosynthetic rate per area $\left(\mu \mathrm{mol} \mathrm{CO}_{2} \mathrm{~m}^{-2} \mathrm{~s}^{-1}\right) ; \mathrm{A}_{\text {mass' }}$ photosynthetic rate per mass ( $\left.\mathrm{nmol} \mathrm{CO} \mathrm{g} \mathrm{g}^{-1} \mathrm{~s}^{-1}\right) ; \mathrm{C}_{\text {area }}$ carbon content per area $\left(\mathrm{g} \mathrm{C} \mathrm{m}^{-2}\right) ; \mathrm{C}_{\text {mass }}$ carbon concentration $\left(\mathrm{mg} \mathrm{g}^{-1}\right)$; $\mathrm{Chl}$ index, chlorophyll index (no units); $\mathrm{Ci} / \mathrm{Ca}$, ratio internal vs external $\mathrm{CO}_{2}$ concentration; gs area, stomatal conductance per area $\left(\mathrm{mmol} \mathrm{H}_{2} \mathrm{O} \mathrm{m} \mathrm{m}^{-2} \mathrm{~s}^{-1}\right)$; $\mathrm{gs}_{\text {mass' }}$ stomatal conductance per mass ( $\mathrm{mmol} \mathrm{H}_{2} \mathrm{O} \mathrm{g}^{-1} \mathrm{~s}^{-1}$ ); LCP, light compensation point ( $\mu$ mol photons $\mathrm{m}^{-2} \mathrm{~s}^{-1}$ ); LSP, light saturation point ( $\mu$ mol photons $\left.\mathrm{m}^{-2} \mathrm{~s}^{-1}\right) ; \mathrm{N}_{\text {area }}$, nitrogen content per area $\left(\mathrm{g} \mathrm{N} \mathrm{m}^{-2}\right) ; \mathrm{N}_{\text {mass }}$, nitrogen concentration $\left(\mathrm{mg} \mathrm{g}^{-1}\right) ; R_{\text {area }}$, respiration rate per area $(\mu \mathrm{mol}$ $\left.\mathrm{CO}_{2} \mathrm{~m}^{-2} \mathrm{~s}^{-1}\right) ; \mathrm{R}_{\text {mass }}$, respiration rate per mass $\left(\mathrm{nmol} \mathrm{CO} \mathrm{g}^{-1} \mathrm{~s}^{-1}\right) ; \mathrm{PNUE}$, photosynthetic nitrogen-use efficiency $\left(\mu \mathrm{mol} \mathrm{CO}{ }_{2}\left(\mathrm{~mol} \mathrm{~N}^{-1} \mathrm{~s}^{-1}\right) ; \mathrm{SLA}_{\text {, }}\right.$ specific leaf area $\left(\mathrm{cm}^{2} \mathrm{~g}^{-1}\right)$; WUE, water-use efficiency $\left(\mu \mathrm{mol} \mathrm{CO}_{2}\left(\mathrm{mmol} \mathrm{H}_{2} \mathrm{O}\right)^{-1}\right)$.

Table 4 Pearson's correlation coefficients for some structural and physiological traits. Bold and normal letters represent high- (HW) and low(LW) water treatments, respectively

\begin{tabular}{|c|c|c|c|c|c|c|c|c|c|c|}
\hline & & $A_{\text {mass }}$ & $\mathrm{gs}_{\text {mass }}$ & PNUE & $R_{\text {mass }}$ & $C_{\text {mass }}$ & $\mathrm{N}_{\text {mass }}$ & SLA & WUE & LSP \\
\hline \multirow[t]{2}{*}{ LCP } & $\mathrm{HW}$ & -0.16 & -0.05 & -0.07 & $0.61 * * *$ & -0.02 & -0.18 & $-0.53^{* *}$ & $\underline{-0.36^{*}}$ & $0.59 * * *$ \\
\hline & LW & $-0.76^{* * *}$ & $-0.75^{* * *}$ & $-0.75^{* * *}$ & 0.05 & 0.24 & $-0.56^{* * *}$ & $-0.61 * * *$ & $\overline{0.07}$ & 0.30 \\
\hline \multirow[t]{2}{*}{ LSP } & $\mathrm{HW}$ & 0.18 & $0.38^{*}$ & $0.36^{*}$ & $0.41^{* *}$ & -0.15 & $-0.33^{*}$ & $-0.49 * *$ & $-0.41^{*}$ & \\
\hline & LW & -0.28 & -0.17 & $-0.30 *$ & -0.15 & 0.20 & $\overline{-0.11}$ & $\overline{-0.31} *$ & -0.30 & \\
\hline \multirow[t]{2}{*}{ WUE } & $\mathrm{HW}$ & -0.15 & $-0.62 * * *$ & -0.28 & -0.19 & 0.16 & 0.22 & 0.28 & & \\
\hline & LW & -0.09 & -0.27 & -0.03 & -0.22 & -0.17 & -0.26 & -0.12 & & \\
\hline \multirow[t]{2}{*}{ SLA } & $\mathrm{HW}$ & $0.46^{* *}$ & 0.24 & 0.14 & 0.26 & $-0.40^{*}$ & $0.71 * * *$ & & & \\
\hline & LW & $0.74 * * *$ & $0.74 * * *$ & $0.66^{* * *}$ & $0.56 * * *$ & $-0.43^{* *}$ & $0.80 * * *$ & & & \\
\hline \multirow[t]{2}{*}{$N_{\text {mass }}$} & $\mathrm{HW}$ & $0.36^{*}$ & 0.15 & -0.11 & $\underline{0.34^{*}}$ & -0.21 & & & & \\
\hline & LW & $0.74 * * *$ & $0.78 * * *$ & $0.61 * * *$ & $\overline{0.49} * *$ & -0.25 & & & & \\
\hline \multirow{2}{*}{$\mathrm{C}_{\text {mass }}$} & $\mathrm{HW}$ & $-0.57^{* * *}$ & $-0.57^{* * *}$ & $-0.51^{* *}$ & $-0.35^{*}$ & & & & & \\
\hline & LW & $-0.43^{* *}$ & $-0.39^{*}$ & $-0.44^{* *}$ & $\overline{-0.30}$ & & & & & \\
\hline \multirow{2}{*}{$\mathrm{R}_{\text {mass }}$} & $\mathrm{HW}$ & $0.38^{*}$ & $0.42 * *$ & 0.25 & & & & & & \\
\hline & LW & $0.45^{* *}$ & $0.43^{* *}$ & $0.40^{* *}$ & & & & & & \\
\hline \multirow[t]{2}{*}{ PNUE } & $\mathrm{HW}$ & $0.89 * * *$ & $0.83 * * *$ & & & & & & & \\
\hline & LW & $0.98 * * *$ & $0.94 * * *$ & & & & & & & \\
\hline \multirow{2}{*}{$\mathrm{gs}_{\text {mass }}$} & $\mathrm{HW}$ & $0.85 * * *$ & & & & & & & & \\
\hline & LW & $0.97 * * *$ & & & & & & & & \\
\hline
\end{tabular}

The level of significance $\left({ }^{*}, P<0.05 ;{ }^{*}, P<0.01 ;{ }^{*}{ }^{*}, P<0.001\right)$ is indicated; those values not remaining significant after controlling the false discovery rate are underlined. $\mathrm{C}_{\text {mass' }}$ carbon concentration $\left(\mathrm{mg} \mathrm{g}^{-1}\right)$; gs $\mathrm{gsss}$ stomatal conductance per mass $\left(\mathrm{mmol} \mathrm{H}_{2} \mathrm{O} \mathrm{g} \mathrm{g}^{-1}\right)$; LCP, light compensation point ( $\mu \mathrm{mol}$ photons $\mathrm{m}^{-2} \mathrm{~s}^{-1}$ ); LSP, light saturation point ( $\mu \mathrm{mol}$ photons $\left.\mathrm{m}^{-2} \mathrm{~s}^{-1}\right) ; \mathrm{N}_{\text {mass' }}$, nitrogen concentration $\left(\mathrm{mg} \mathrm{g}^{-1}\right) ; \mathrm{R}_{\text {area' }}$ respiration rate per area $\left(\mu \mathrm{mol} \mathrm{CO} \mathrm{Cm}^{-2} \mathrm{~s}^{-1}\right)$; PNUE, photosynthetic nitrogen-use efficiency $\left(\mu \mathrm{mol} \mathrm{CO}_{2}(\mathrm{~mol} \mathrm{~N})^{-1} \mathrm{~s}^{-1}\right)$; SLA, specific leaf area $\left(\mathrm{cm}^{2} \mathrm{~g}^{-1}\right)$; WUE, water-use efficiency $\left(\mu \mathrm{mol} \mathrm{CO} 2\left(\mathrm{mmol} \mathrm{H}_{2} \mathrm{O}\right)^{-1}\right)$. 
New

Phytologist
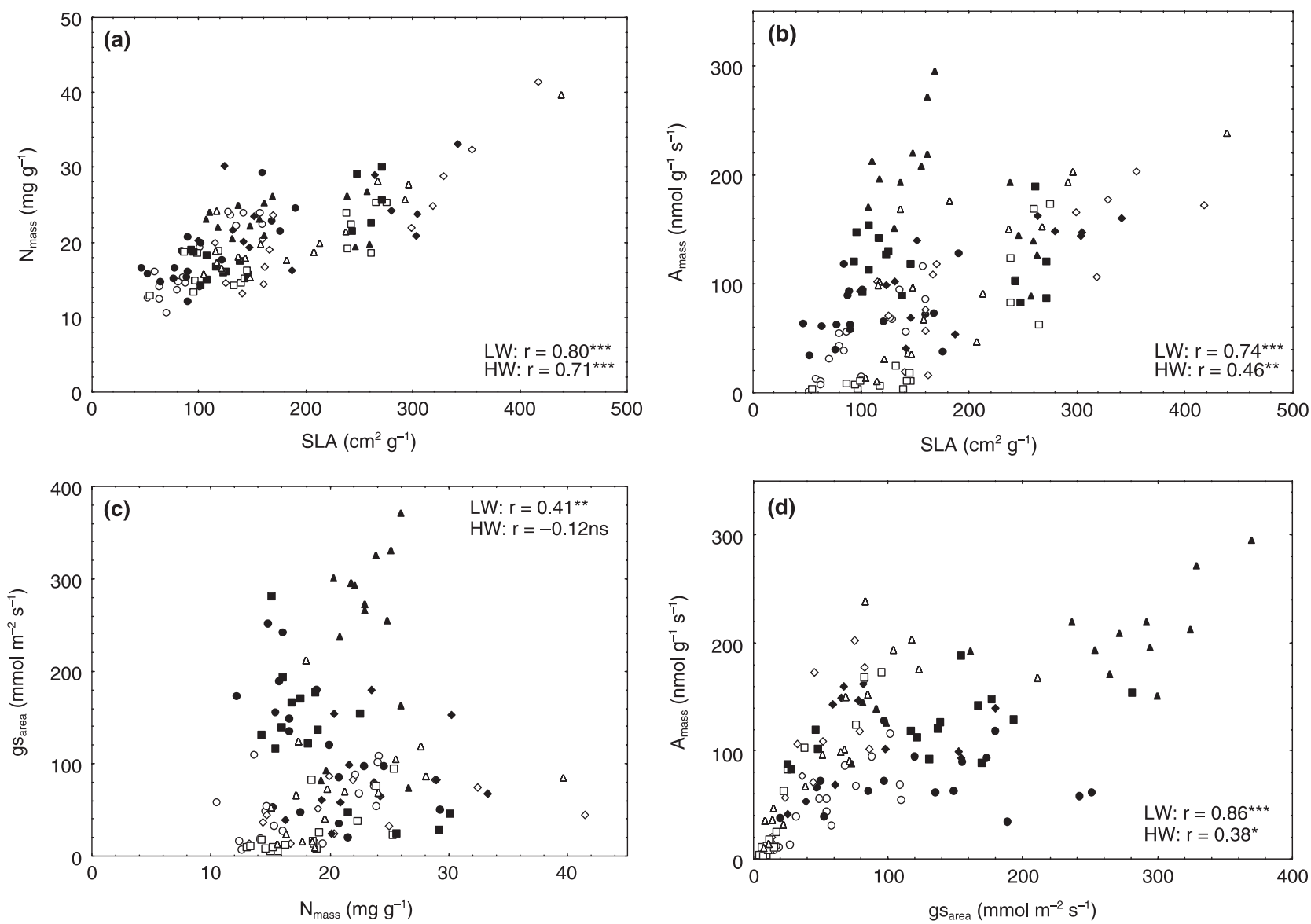

Fig. 4 Correlations between leaf traits. (a) Nitrogen concentration $\left(N_{\text {mass }}\right)$ and (b) photosynthetic rate on mass basis $\left(A_{\text {mass }}\right)$ vs specific leaf area

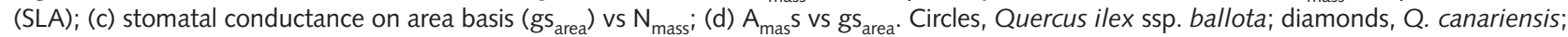
squares, Q. suber; triangles, Q. pyrenaica. Values for seedlings grown under high-water conditions (closed symbols) are distinguished from those grown under low-water conditions (open symbols).

Table 5 Probabilities under the null hypothesis that the data accord with each of the six proposed models, for each of the treatment conditions and combinations using the $d$-sep method

\begin{tabular}{|c|c|c|c|c|c|c|}
\hline \multirow[b]{2}{*}{ Treatment } & \multicolumn{6}{|c|}{ Model type } \\
\hline & A & B & C & $\mathrm{D}$ & $\mathrm{E}$ & $\mathrm{F}$ \\
\hline HI HW & 0.02258 & $\underline{0.01406}$ & 0.66464 & $\underline{0.01595}$ & 0.81801 & 0.36896 \\
\hline HI LW & 0.66877 & $\overline{0.41394}$ & 0.74490 & $\overline{0.48724}$ & 0.07526 & 0.50847 \\
\hline MI HW & 0.46033 & 0.52570 & 0.79599 & 0.34195 & 0.72478 & 0.67319 \\
\hline MI LW & 0.45570 & 0.45980 & 0.57111 & 0.66589 & 0.64803 & 0.32076 \\
\hline LI HW & $\underline{0.00745}$ & $\underline{0.01084}$ & 0.09345 & 0.23975 & 0.16812 & 0.11715 \\
\hline LI LW & 0.01414 & 0.00251 & 0.07707 & 0.42238 & 0.06243 & 0.02955 \\
\hline $\mathrm{HI}$ & $\overline{0.78200}$ & $\overline{0.14879}$ & 0.98447 & 0.11576 & 0.00618 & 0.95464 \\
\hline MI & 0.48803 & 0.47054 & 0.26774 & 0.93449 & $\overline{0.01079}$ & 0.13347 \\
\hline LI & $\underline{0.00001}$ & $\underline{0.00000}$ & $\underline{0.00623}$ & 0.02383 & 0.01079 & 0.01376 \\
\hline HW & $\overline{0.14121}$ & $\overline{0.05122}$ & $\overline{0.07750}$ & 0.6833 & $\overline{0.08963}$ & $\overline{0.19061}$ \\
\hline LW & $\underline{0.02473}$ & $\underline{0.00759}$ & 0.52332 & 0.10452 & $\underline{0.01823}$ & 0.39736 \\
\hline $\mathrm{HI}+\mathrm{MI}$ & $\overline{0.44674}$ & $\overline{0.09157}$ & 0.46729 & 0.35493 & $\overline{0.00001}$ & 0.22299 \\
\hline Combined & 0.00044 & 0.00000 & 0.00017 & 0.17411 & 0.00000 & 0.00356 \\
\hline
\end{tabular}

HI, high irradiance; MI, medium irradiance; LI, low irradiance or deep shade; HW, high water; LW, nonwatered (drought). Models that would be rejected at the $5 \%$ level on a per-test basis are shown in bold type. However those whose values remained significant after controlling the False Discovery Rate (FDR) at the $5 \%$ level, following the Ventura et al. (2004) criteria, are underlined. 

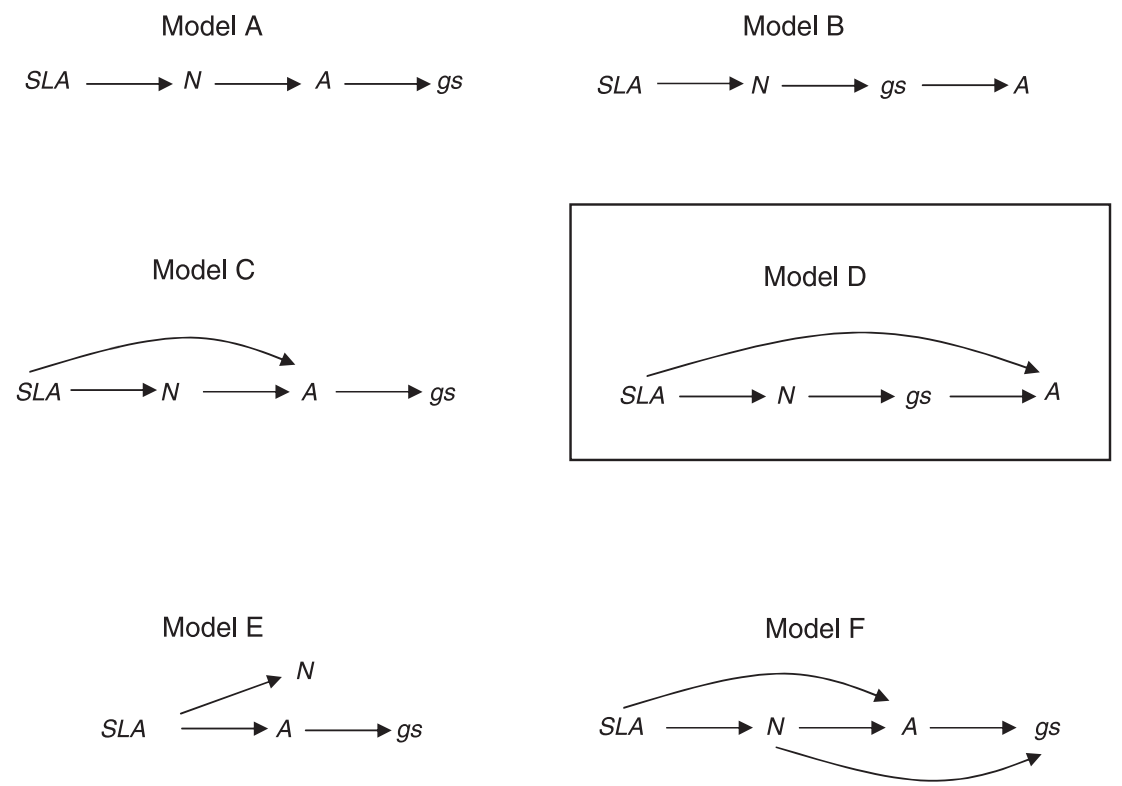

Fig. 5 Alternative multivariate models linking the specific leaf area (SLA), leaf nitrogen content on mass basis $(N)$, net photosynthetic rate on mass basis (A), and stomatal conductance on mass basis (gs). Model D (framed) was the best fitted to the dataset of Quercus seedling responses to water and light treatments. grown under deep shade increased their SLA, but they did not necessarily have a lower physiological performance, in terms of net photosynthetic rate, stomatal conductance or WUE when subjected to drought, as would be expected from the trade-off hypothesis (Smith \& Huston, 1989). By contrast, under similar drought conditions, deep-shaded seedlings were able to achieve higher photosynthetic rate, stomatal conductance, and $\mathrm{N}$ concentration than seedlings under full light (Fig. 2). Moreover, under drought conditions, seedlings with higher SLA had higher $\mathrm{A}_{\text {area }}$ while lower $\mathrm{R}_{\text {area }}$, indicating a higher positive $\mathrm{C}$ balance in these leaves (Table 4). The apparent alleviation of drought impact for seedlings growing in shade, demonstrated here under experimental conditions, could explain the pattern of higher seedling survival under shade of shrubs and trees (facilitation effect), commonly observed in Mediterranean forests (Castro et al., 2004b; Gómez-Aparicio et al., 2004; Marañón et al., 2004).

Other studies have also found structural and physiological evidence supporting the hypothesis of shade as lessening the drought stress on seedlings of woody species (Holmgren, 2000; Prider \& Facelli, 2004; Duan et al., 2005). Conversely, plants under high irradiance, when subjected to water stress, suffer a more drastic reduction in net photosynthesis, and can be more predisposed to photo-inhibition, in comparison with plants in the shade (see References in Holmgren, 2000); although sunflecks can cause severe photoinhibition in shaded leaves (Valladares \& Pearcy, 2002). However, Sack \& Grubb (2002) and Sack (2004) found that the effect of shade and drought showed orthogonal impacts (no interactions) on final dry mass, relative growth rate, and biomass allocation on seedlings of different species. The authors proposed that seedlings are able to tolerate both shade and drought by developing plant features conferring reduced demand for light and/or water (see References in Sack \& Grubb, 2002).
By contrast, there are studies showing negative responses to combined shade and drought conditions for Quercus species. In a controlled experiment, Q. suber seedlings grown in shade were less efficient in developing physiological mechanisms of water tolerance, in particular, osmotic adjustment and effective control of water loss (Aranda et al., 2005). This has been found in field studies with other woody species (Valladares \& Pearcy, 2002).

These contrasting results indicate that, physiological and structural mechanisms involved in the integrated responses of the tree seedlings to shade and drought strongly depend on plant functional type.

\section{Do species or functional groups (evergreen vs deciduous) respond differently?}

Seedlings of the deciduous species here (Q. pyrenaica and Q. canariensis) differed in leaf structure (higher values for leaf area, SLA and N, but lower chlorophyll concentrations) and in physiological activities (higher values of photosynthetic and respiration rates, stomatal conductance and PNUE) compared with seedlings of evergreen oaks ( $Q$. ilex and $Q$. suber) subjected to the same conditions of light and water. A similar trend in structural and physiological differences between seedlings, associated with the contrasted leaf habit (deciduous vs evergreen) of adults, has been documented for other Mediterranean species (Villar et al., 1995; Villar \& Merino, 2001). Within the same genus Quercus, Takashima et al. (2004) found that the PNUE in evergreen species was lower than in deciduous ones; in evergreen oak seedlings the allocation of $\mathrm{N}$ to photosynthesis was smaller, while that to cell walls was greater, in order to acquire leaf toughness.

In general, leaf traits of seedlings of deciduous species allow them to achieve a higher relative growth rate than that of 
seedlings of congeneric, evergreen species (Antunez et al., 2001; Ruiz-Robleto \& Villar, 2005).

\section{Which physiological and structural leaf traits are most affected by the combined stress?}

Leaf response to irradiance was very variable, in both structural and physiological traits (Fig. 3). For example, shade induced a relatively high variation in the key leaf trait SLA for all four oak species (mean Reponse light $_{\text {of }}$ 0.6), similar to the light-induced plasticity values found for evergreen tropical shrubs (16 Psychotria species, mean of 0.4; Valladares et al., 2000b). The ability to respond to light by modifying leaf structural traits may confer shade tolerance by increasing light-capture efficiency (Valladares et al., 2002b). At the same time, the relatively high responsiveness of leaf physiology may also indicate a tolerance to high irradiance (Valladares et al., 2002a).

Drought induced a relatively low response in structural leaf traits but a high one in physiological traits (Fig. 3). In this experiment, we have simulated the Mediterranean climate seasonal drought that predictably occurs a few months after seedling emergence. When drought stress becomes more severe, first-year seedlings, grown under varied irradiance conditions, have already completed their growth, and therefore have low ability to modify structural leaf traits, which usually have a large ontogenetic component. However, they show a high physiological responsiveness to optimize photosynthesis : transpiration ratios under drought conditions.

\section{What are the functional relationships among variables?}

Because bivariate relationships are unsuccessful for making causal inferences, we tested several causal models of multivariate links among structural (SLA and $\mathrm{N}_{\text {mass }}$ ) and physiological $\left(\mathrm{A}_{\text {mass }}\right.$ and $\mathrm{gs}$ mass $_{\text {) }}$ ) leaf traits (Fig. 5) and accepted one of them (model D) as the best fit to the experiment results. According to this model, there is a direct causal relationship of SLA with dry mass concentration of cytoplasmic constituents, including $\mathrm{N}$, which in turn affects stomatal conductance. Assuming that stomatal behaviour is regulated to maximize WUE, then the passive process of gas exchange across the stomata would result in the net photosynthetic rate (Meziane \& Shipley, 2001). In addition, the model proposes a direct causal relationship of SLA with A, not mediated by leaf N. One explanation is that the accumulation of nonstructural carbohydrates will decrease SLA and reduce photosynthesis (Meziane \& Shipley, 2001). Another explanation is that self-shading of chloroplasts in the lower part of thicker leaves (with lower SLA) will decrease the net $C$ fixation on a leaf-mass basis (Reich et al., 1999). Thus, there is a complex multivariate link among these three leaf traits: the ratio of leaf area to mass (SLA) is balanced with the amount of organic leaf $\mathrm{N}$ per mass $\left(\mathrm{N}_{\text {mass }}\right)$ to maximize photosynthesis rate $\left(\mathrm{A}_{\text {mass }}\right)$ mediated by stomatal conductance $\left(\mathrm{gs}_{\text {mass }}\right)$, hence optimizing loss of water by transpiration, which is so important in Mediterranean environments.

\section{Ecological significance}

The four Mediterranean oak species studied here share a general syndrome of leaf traits that can be suited to a 'reduced demand for resources' (Sack et al., 2003), as well as part of a 'conservative resource-use strategy' (Valladares et al., 2000a). Although in the physiological literature these traits are usually considered adaptations to the dry Mediterranean climate, most probably they are ancestral traits of Tertiary subtropical oaks, which allowed them to be sorted in when the climatic change imposing the seasonal drought typical of Mediterranean climate became established c. 3.5 million years ago (Herrera, 1992).

Within that general 'Mediterranean oak syndrome', there are interspecific differences in the seedling responses to light and water. The changes in structural leaf traits of leaf area, SLA, and concentrations of $\mathrm{N}$ and $\mathrm{C}$, and the physiological performance of photosynthetic and respiration rates, and $\mathrm{N}$ efficiency (PNUE), were the most affected by the species factor in this experiment. These leaf traits are associated with the plant's physiological response to the abundance of resources, and determine their growth and survivorship (Lambers \& Poorter, 1992; Wright et al., 2004). For example, the seedlings of $Q$. pyrenaica showed the highest values of $A_{\text {area }}, A_{\text {mass }} g s_{\text {area' }}$, $g s_{\text {mass }}$, leaf area and PNUE compared with the other three oak species. These leaf traits would favour seedling growth in nutrient-rich and mesic habitats, but they may confer less tolerance to drought (see species distribution in Table 1).

Mediterranean drought, at all levels of light, is a problem for the seedling in terms of avoiding water loss and maintaining $\mathrm{C}$ uptake, and therefore of biomass gain. On the other hand, deep shade in the closed forest understorey environment, independently of water availability, can be a limiting factor in maintaining a positive $\mathrm{C}$ balance. In this experiment, the shade conditions seemed to ameliorate, or at least not aggravate, the drought impact on oak seedlings therefore drought response on leaf performance depend of light environment.

\section{Acknowledgements}

We thank the glasshouse staff of the University of Córdoba for their advice and Miguel Ángel Calero, Carlos Casimiro, Loles Bejarano, Ana Murillo, Juan Rubio, Francisco Conde, Francisco J. Morilla and Miguel A. Nuñez for their help during the experiment. We thank Lawren Sack, Fernando Valladares and Steve Long for their comments on a previous version of the manuscript, Luis V. García for his help with numerical analysis and Esteban Alcántara for his help with chlorophyll determinations. We thank three anonymous referees for comments and improvements on the manuscript. This study was supported by the grant FPI-MEC to J.L.Q. (BES-2003-1716), and by 
the coordinated Spanish CICYT project HETEROMED (REN2002-04041). This research is part of the REDBOME network on forest ecology (http://www.ugr.es/ redbome/).

\section{References}

Abrams MD, Mostoller SA. 1995. Gas exchange, leaf structure and nitrogen in contrasting successional tree species growing in open and understory sites during a drought. Tree Physiology 15: 361-370.

Amaral J. 1990. Quercus. In: Castroviejo S, Laínz M, López González G, Montserrat P, Muñoz Garmendia F, Paiva J, Villar L, eds. Flora Iberica, Vol. II. Madrid, Spain: Real Jardín Botánico, CSIC, 15-36.

Antunez I, Retamosa EC, Villar R. 2001. Relative growth rate in phylogenetically related deciduous and evergreen woody species. Oecologia 128: 172-180.

Aranda I, Castro L, Pardos M, Gil L, Pardos JA. 2005. Effects of the interaction between drought and shade on water relations, gas exchange and morphological traits in cork oak Quercus suber L. seedlings. Forest Ecology and Management 210: 117-129.

Canham CD, Berkowitz AR, Kelly VR, Lovett GM, Ollinger SV, Schnurr J. 1996. Biomass allocation and multiple resource limitation in tree seedlings. Canadian Journal of Forest Research 26: 1521-1530.

Castro J, Zamora R, Hódar JA, Gómez JM, Gómez-Aparicio L. 2004a. Benefits of using shrubs as nurse plants for reforestation in Mediterranean mountains: a 4-year study. Restoration Ecology 12 : 352-358.

Castro J, Zamora R, Hódar JA, Gómez JM. 2004b. Seedling establishment of a boreal tree species Pinus sylvestris at its southernmost distribution limit: consequences of being in a marginal, Mediterranean habitat. Journal of Ecology 92: 266-277.

Cavender-Bares J, Bazzaz FA. 2000. Changes in drought response strategies with ontogeny in Quercus rubra: implications for scaling from seedlings to mature trees. Oecologia 124: 8-18.

Duan B, Lu Y, Yin C, Junttila O, Li C. 2005. Physiological responses to drought and shade in two contrasting Picea asperata populations. Physiologia Plantarum 124: 476-484.

Field C, Mooney HA. 1986. The photosynthesis-nitrogen relationship in wild plants. In: Givinish TJ, ed. On the economy of plant form and function. Cambridge, UK: Cambridge University Press, 25-55.

García LV. 2004. Escaping the Bonferroni iron claw in ecological studies. Oikos 105: 657-663.

Gómez-Aparicio L, Zamora R, Gómez JM, Hódar JA, Castro J, Baraza E. 2004. Applying plant facilitation to forest restoration in Mediterranean ecosystems: a meta-analysis of the use of shrubs as nurse plants. Ecological Applications 14: 1128-1138.

Gómez-Aparicio L, Valladares F, Zamora R, Quero JL. 2005. Response of tree seedlings to the abiotic heterogeneity generated by nurse shrubs: an experimental approach at different scales. Ecography 28: 757-768.

Herrera CM. 1992. Historical effects and sorting processes as explanations for contemporary ecological patterns: character syndromes in Mediterranean woody plants. American Naturalist 140: 421-446.

Holmgren M. 2000. Combined effects of shade and drought on tulip poplar seedlings: trade-off in tolerance or facilitation? Oikos 90: 67-78.

Kubiske ME, Pregitzer KS. 1996. Effects of elevated $\mathrm{CO}_{2}$ and light availability on the photosynthetic response of trees of contrasting shade tolerance. Tree Physiology 16: 351-358.

Lambers H, Poorter H. 1992. Inherent variation in growth rate between higher plants: a search for physiological causes and ecological consequences. Advances in Ecological Research 23: 187-261.

Marañón T, Zamora R, Villar R, Zavala MA, Quero JL, Pérez-Ramos I, Mendoza I, Castro J. 2004. Regeneration of tree species and restoration under contrasted Mediterranean habitats: field and glasshouse experiments. International Journal of Ecology and Environmental Sciences 30: $187-196$.

Meziane D, Shipley B. 2001. Direct and indirect relation between specific leaf area, leaf nitrogen and leaf gas exchange effects of irradiance and nutrient supply. Annals of Botany 88: 915-917.

Prider JN, Facelli JM. 2004. Interactive effects of drought and shade on three arid zone chenopod shrubs with contrasting distributions in relation to tree canopies. Functional Ecology. 18: 67-76.

Reich PB, Ellsworth DS, Walters MB, Vose JM, Gresham C, Volin JC, Bowman WD. 1999. Generality of leaf trait relationships: a test across six biomes. Ecology 80: 1955-1969.

Reich PB, Walters MB, Ellsworth DS. 1992. Leaf lifespan in relation to leaf, plant and stand characteristics among diverse ecosystems. Ecological Monographs 62: 365-392.

Reich PB, Walters MB, Ellsworth DS. 1997. From tropics to tundra: global convergence in plant functioning. Proceedings of the National Academy of Sciences, USA 94: 13730-13734.

Rey-Benayas JM, Navarro J, Espigares T, Nicolau JM, Zavala MA. 2005. Effects of artificial shading and weed mowing in reforestation of Mediterranean abandoned cropland with contrasting Quercus species. Forest Ecology and Management 212: 302-314.

Ruiz-Robleto J, Villar R. 2005. Relative growth rate and biomass allocation in 10 woody species with different leaf longevity using phylogenetic independent contrasts PICs. Plant Biology 7: 484-494.

Sack L. 2004. Responses of temperate woody seedlings to shade and drought: do trade-offs limit potential niche differentiation? Oikos 107: $110-127$.

Sack L, Grubb PJ. 2002. The combined impacts of deep shade and drought on the growth and biomass allocation of shade-tolerant woody seedlings. Oecologia 131: 175-185.

Sack L, Grubb PJ, Marañón T. 2003. The functional morphology of juvenile plants tolerant of strong summer drought in shaded forest understories in southern Spain. Plant Ecology 168: 139-163.

Shipley B. 2000. A new inferential test for path models based on directed acyclic graphs. Structural Equation Modelling 7: 206-218.

Smith T, Huston M. 1989. A theory of the spatial and temporal dynamics of plant communities. Vegetatio 83: 49-69.

Takashima T, Hikosaka K, Hirose T. 2004. Photosynthesis or persistence: nitrogen allocation in leaves of evergreen and deciduous Quercus species. Plant, Cell \& Environment 27: 1047-1054.

Thornley JHM. 1976. Mathematical models in plant physiology. New York, NY, USA: Academic Press.

Urbieta IR, Zavala MA, Marañón T. 2004. Distribución y abundancia de alcornoque Quercus suber L. y quejigo Quercus canariensis Willd. y su relación con factores ambientales en la provincia de Cádiz. Revista de la Sociedad Gaditana de Historia Natural 4: 183-189.

Valladares F, Pearcy RW. 2002. Drought can be more critical in the shade than in the sun: a field study of carbon gain and photo-inhibition in a Californian shrub during a dry El Niño year. Plant, Cell \& Environment 25: 749-759.

Valladares F, Martínez-Ferri E, Balaguer L, Pérez-Corona E, Manrique E. 2000a. Low leaf-level response to light and nutrients in Mediterranean evergreen oaks: a conservative resource-use strategy? New Phytologist 148: 79-91.

Valladares F, Wright SJW, Lasso E, Kitajima K, Pearcy RW. 2000b. Plastic phenotypic response to light of 16 congeneric shrubs from a Panamanian rainforest. Ecology 81: 1925-1936.

Valladares F, Chico JM, Aranda I, Balaguer L, Dizengremel P, Manrique E, Dreyer E. 2002a. The greater seedling high-light tolerance of Quercus robur and over Fagus sylvatica is linked to a greater physiological plasticity. Trees, Structure and Function 16: 395-403.

Valladares F, Skillman J, Pearcy RW. 2002b. Convergence in light capture efficiencies among tropical forest understory plants with contrasting crown architectures: a case of morphological compensation. American Journal of Botany 89: 1275-1284. 
New

Phytologist

Ventura V, Paciorek CJ, Risbey JS. 2004. Controlling the proportion of falsely rejected hypotheses when conducting multiple tests with climatological data. Journal of Climate 17: 4343-4356.

Villar R, Held AA, Merino J. 1995. Dark leaf respiration in light and darkness of an evergreen and a deciduous plant-species. Plant Physiology 107: 421-427.

Villar R, Merino J. 2001. Comparison of leaf construction costs in woody species with differing leaf life-spans in contrasting ecosystems. New Phytologist 151: 213-226.
Wright IJ, Reich PB, Westoby M, Ackerly DD, Baruch Z, Bongers F, Cavender-Bares J, Chapin T, Cornelissen JHC, Diemer M, Flexas J, Garnier E, Groom PK, Gulias J, Hikosaka K, Lamont BB, Lee T, Lee W, Lusk C, Midgley JJ, Navas ML, Niinemets U, Oleksyn J, Osada N, Poorter H, Poot P, Prior L, Pyankov VI, Roumet C, Thomas SC, Tjoelker MG, Veneklaas EJ, Villar R. 2004. The worldwide leaf economics spectrum. Nature 428: 821-827.

Zar JH. 1984. Biostatistical analysis, 2nd edn. Englewood Cliffs, NJ, USA: Prentice Hall. 


\section{Appendix 1}

Mean \pm SE values of structural and physiological leaf traits analysed for Quercus seedlings in different light and water treatments. In general, there were four replicates per treatments, exceptions are indicated in parentheses

\begin{tabular}{|c|c|c|c|c|c|c|}
\hline \multirow[b]{2}{*}{ Trait } & \multicolumn{2}{|l|}{$\mathrm{HI}$} & \multicolumn{2}{|l|}{$\mathrm{MI}$} & \multicolumn{2}{|l|}{$\mathrm{LI}$} \\
\hline & $\mathrm{LW}$ & HW & LW & $\mathrm{HW}(n=3)$ & LW & HW \\
\hline \multicolumn{7}{|c|}{ Quercus suber (evergreen) } \\
\hline \multicolumn{7}{|c|}{ Structural traits } \\
\hline Area & $9.2 \pm 0.6$ & $10.8 \pm 0.6$ & $12.6 \pm 0.6$ & $12.1 \pm 0.8$ & $8.3 \pm 0.5$ & $9.9 \pm 0.8$ \\
\hline SLA & $90.32 \pm 6.61$ & $101.62 \pm 3.38$ & $137.59 \pm 3.17$ & $131.01 \pm 5.71$ & $246.85 \pm 6.84$ & $259.54 \pm 4.81$ \\
\hline $\mathrm{N}_{\text {mass }}$ & $15.66 \pm 1.09$ & $17.21 \pm 0.88$ & $15.68 \pm 0.67$ & $16.54 \pm 0.54$ & $22.13 \pm 1.05$ & $26.34 \pm 1.92$ \\
\hline $\mathrm{C}_{\text {mass }}$ & $480.3 \pm 4.2$ & $446.1 \pm 5.7$ & $468.9 \pm 4.4$ & $455.9 \pm 6.7$ & $470.1 \pm 3.3$ & $456.7 \pm 13.1$ \\
\hline $\mathrm{N}_{\text {area }}$ & $1.77 \pm 0.19$ & $1.71 \pm 0.13$ & $1.15 \pm 0.06$ & $1.27 \pm 0.06$ & $0.90 \pm 0.04$ & $1.02 \pm 0.08$ \\
\hline$C_{\text {area }}^{\text {died }}$ & $5.52 \pm 0.58$ & $4.40 \pm 0.11$ & $3.43 \pm 0.12$ & $3.50 \pm 0.11$ & $1.91 \pm 0.06$ & $1.76 \pm 0.06$ \\
\hline Chl index & $19.2 \pm 2.1$ & $26.5 \pm 2.9$ & $24.4 \pm 0.5$ & $29.1 \pm 1.8$ & $24.4 \pm 1.9$ & $29.4 \pm 2.5$ \\
\hline \multicolumn{7}{|c|}{ Physiological traits } \\
\hline$\Phi$ & $0.0274 \pm 0.0118$ & $0.0470 \pm 0.0029$ & $0.0312 \pm 0.009$ & $0.0531 \pm 0.003$ & $0.0438 \pm 0.0044$ & $0.0450 \pm 0.004$ \\
\hline$\theta$ & $0.545 \pm 0.273$ & $0.931 \pm 0.023$ & $0.766 \pm 0.124$ & $0.727 \pm 0.107$ & $0.927 \pm 0.034$ & $0.827 \pm 0.089$ \\
\hline LCP & $45.2 \pm 1.2$ & $15.1 \pm 3.7$ & $27.0 \pm 8.0$ & $13.4 \pm 1.5$ & $6.5 \pm 1.3$ & $10.0 \pm 1.7$ \\
\hline LSP & $735.0 \pm 155.8$ & $395.2 \pm 74.4$ & $337.2 \pm 100.4$ & $517.3 \pm 129.3$ & $155.1 \pm 27.1$ & $227.7 \pm 74.0$ \\
\hline$A_{\text {area }}$ & $0.94 \pm 0.25$ & $12.72 \pm 0.97$ & $1.08 \pm 0.32$ & $10.5 \pm 1.80$ & $4.48 \pm 0.40$ & $4.29 \pm 0.51$ \\
\hline$R_{\text {area }}^{\text {area }}$ & $0.56 \pm 0.10$ & $0.73 \pm 0.19$ & $0.37 \pm 0.06$ & $0.69 \pm 0.06$ & $0.26 \pm 0.04$ & $0.42 \pm 0.05$ \\
\hline $\begin{array}{l}\text { ared } \\
\text { gs area }\end{array}$ & $14.3 \pm 4.3$ & $166.0 \pm 29.4$ & $11.4 \pm 2.3$ & $179.7 \pm 20.9$ & $51.6 \pm 11.9$ & $56.1 \pm 19.6$ \\
\hline$A_{\text {mass }}$ & $6.9 \pm 1.5$ & $126.8 \pm 9.2$ & $14.8 \pm 4.2$ & $115.7 \pm 13.7$ & $111.1 \pm 11.4$ & $121.6 \pm 23.7$ \\
\hline $\mathrm{R}_{\text {mass }}$ & $4.6 \pm 1.1$ & $7.7 \pm 2.2$ & $5.1 \pm 0.9$ & $8.5 \pm 0.6$ & $6.6 \pm 1.1$ & $10.7 \pm 1.0$ \\
\hline $\mathrm{gs}_{\text {mass }}$ & $0.10 \pm 0.02$ & $1.78 \pm 0.42$ & $0.16 \pm 0.03$ & $2.07 \pm 0.15$ & $1.28 \pm 0.31$ & $1.72 \pm 0.78$ \\
\hline WUE & $76.6 \pm 8.2$ & $80.1 \pm 7.0$ & $10.6 \pm 2.3$ & $57.8 \pm 7.0$ & $96.5 \pm 11.8$ & $93.7 \pm 13.9$ \\
\hline PNUE & $5.97 \pm 1.26$ & $104.68 \pm 13.04$ & $13.58 \pm 4.20$ & $98.72 \pm 13.87$ & $70.89 \pm 5.52$ & $67.50 \pm 17.00$ \\
\hline $\mathrm{Ci} / \mathrm{Ca}$ & $0.62 \pm 0.03$ & $0.52 \pm 0.02$ & $0.49 \pm 0.01$ & $0.63 \pm 0.04$ & $0.51 \pm 0.05$ & $0.53 \pm 0.05$ \\
\hline
\end{tabular}

$\mathrm{HI}$

Trait
MI

LW
LI

LW

Quercus ilex ssp. ballota (evergreen)

Structural traits

$\begin{array}{lc}\text { Area } & 7.9 \pm 0.8 \\ \mathrm{SLA} & 61.00 \pm 1.27 \\ \mathrm{~N}_{\text {mass }} & 13.65 \pm 1.31 \\ \mathrm{C}_{\text {mass }} & 481.8 \pm 1.9 \\ \mathrm{~N}_{\text {area }} & 2.27 \pm 0.24 \\ \mathrm{C}_{\text {area }} & 7.98 \pm 0.16 \\ \text { Chl index } & 35.6 \pm 3.0\end{array}$

Physiological traits

$\begin{array}{lc}\Phi & 0.0163 \pm 0.0051 \\ \theta & 0.805 \pm 0.157 \\ \mathrm{LCP} & 24.3 \pm 1.90 \\ \mathrm{LSP} & 325.0 \pm 65.1 \\ \mathrm{~A}_{\text {area }} & 1.98 \pm 0.25 \\ \mathrm{R}_{\text {area }} & 0.46 \pm 0.18 \\ \text { gs } & 25.7 \pm 4.3 \\ \mathrm{~A}_{\text {mase }} & 12.7 \pm 1.9 \\ \mathrm{R}_{\text {mass }} & 2.9 \pm 1.2 \\ \text { gs } & 0.16 \pm 0.03 \\ \text { WUE } & 86.8 \pm 18.1 \\ \text { PNUE } & 14.01 \pm 3.55 \\ \mathrm{Ci} / \mathrm{Ca} & 0.56 \pm 0.08\end{array}$

$\begin{aligned} 8.4 & \pm 0.3 \\ 64.64 & \pm 8.98 \\ 16.57 & \pm 0.33 \\ 473.8 & \pm 5.5 \\ 2.72 & \pm 0.35 \\ 7.88 & \pm 1.13 \\ 34.5 & \pm 2.7\end{aligned}$

$\begin{aligned} 0.0470 & \pm 0.0081 \\ 0.892 & \pm 0.065 \\ 27.2 & \pm 2.9 \\ 508.0 & \pm 122.0 \\ 9.39 & \pm 1.50 \\ 1.20 & \pm 0.26 \\ 170.1 & \pm 12.3 \\ 59.4 & \pm 9.2 \\ 8.1 & \pm 2.8 \\ 1.03 & \pm 0.15 \\ 58.2 & \pm 10.0 \\ 49.63 & \pm 6.80 \\ 0.64 & \pm 0.05\end{aligned}$

\section{$8.6 \pm 0.9$ \\ $91.68 \pm 5.01$ \\ $15.68 \pm 1.25$ \\ $477.6 \pm 2.1$ \\ $1.71 \pm 0.11$ \\ $5.26 \pm 0.29$ \\ $32.2 \pm 1.9$}

$\begin{aligned} 0.0413 & \pm 0.0033 \\ 0.906 & \pm 0.053 \\ 19.0 & \pm 4.5 \\ 158.8 & \pm 41.4 \\ 3.56 & \pm 1.33 \\ 0.76 & \pm 0.17 \\ 38.4 & \pm 15.5 \\ 30.7 & \pm 10.4 \\ 7.1 & \pm 1.9 \\ 0.33 & \pm 0.12 \\ 89.6 & \pm 7.7 \\ 28.83 & \pm 10.71 \\ 0.54 & \pm 0.04\end{aligned}$

HW
W

\section{HW}


New

Phytologist

Appendix 1 Continued

\begin{tabular}{|c|c|c|c|c|c|c|}
\hline \multirow[b]{2}{*}{ Trait } & \multicolumn{2}{|l|}{$\mathrm{HI}$} & \multicolumn{2}{|l|}{ MI } & \multicolumn{2}{|l|}{$\mathrm{LI}$} \\
\hline & $\operatorname{LW}(n=3)$ & $\mathrm{HW}(n=3)$ & LW & $\operatorname{HW}(n=3)$ & $\operatorname{LW}(n=3)$ & $\mathrm{HW}$ \\
\hline \multicolumn{7}{|c|}{ Quercus canariensis (deciduous) } \\
\hline \multicolumn{7}{|c|}{ Structural traits } \\
\hline Area & $11.2 \pm 0.6$ & $9.5 \pm 0.8$ & $12.6 \pm 1.8$ & $13.6 \pm 5.4$ & $11.7 \pm 0.5$ & $9.1 \pm 1.2$ \\
\hline SLA & $127.81 \pm 13.07$ & $111.57 \pm 11.98$ & $154.83 \pm 9.98$ & $145.76 \pm 5.69$ & $339.72 \pm 23.48$ & $281.32 \pm 8.23$ \\
\hline $\mathrm{N}_{\text {mass }}$ & $16.57 \pm 3.37$ & $25.26 \pm 4.95$ & $18.38 \pm 1.90$ & $21.91 \pm 1.56$ & $29.08 \pm 3.92$ & $24.60 \pm 1.66$ \\
\hline $\mathrm{C}_{\text {mass }}$ & $451.4 \pm 7.6$ & $445.9 \pm 11.4$ & $451.4 \pm 2.4$ & $443.12 \pm 7.14$ & $445.1 \pm 5.3$ & $436.8 \pm 9.1$ \\
\hline $\mathrm{N}_{\text {area }}$ & $1.34 \pm 0.4$ & $2.24 \pm 0.2$ & $1.18 \pm 0.07$ & $1.50 \pm 0.05$ & $0.85 \pm 0.05$ & $0.88 \pm 0.08$ \\
\hline $\mathrm{C}_{\text {area }}^{\text {ared }}$ & $3.58 \pm 0.43$ & $4.03 \pm 0.33$ & $2.9 \pm 0.21$ & $3.04 \pm 0.07$ & $1.32 \pm 0.07$ & $1.59 \pm 0.09$ \\
\hline Chl index & $16.5 \pm 0.9$ & $30.1 \pm 2.2$ & $25.6 \pm 1.4$ & $28.0 \pm 1.4$ & $24.1 \pm 1.4$ & $24.2 \pm 3.9$ \\
\hline \multicolumn{7}{|c|}{ Physiological traits } \\
\hline$\Phi$ & $0.0342 \pm 0.0104$ & $0.0436 \pm 0.0025$ & $0.0325 \pm 0.0048$ & $0.0466 \pm 0.032$ & $0.0478 \pm 0.0020$ & $0.0448 \pm 0.0062$ \\
\hline$\theta$ & $0.308 \pm 0.308$ & $0.744 \pm 0.144$ & $0.927 \pm 0.029$ & $0.760 \pm 0.105$ & $0.929 \pm 0.036$ & $0.896 \pm 0.027$ \\
\hline LCP & $29.7 \pm 4.6$ & $20.5 \pm 4.2$ & $16.4 \pm 4.3$ & $16.0 \pm 1.8$ & $6.6 \pm 1.5$ & $9.1 \pm 4.1$ \\
\hline LSP & $651.8 \pm 256.3$ & $619.7 \pm 129.5$ & $240.5 \pm 49.2$ & $430.4 \pm 0.1$ & $167.03 \pm 47.7$ & $222.9 \pm 38.3$ \\
\hline$A_{\text {area }}$ & $3.71 \pm 2.58$ & $10.54 \pm 1.86$ & $5.14 \pm 0.74$ & $7.45 \pm 1.75$ & $4.85 \pm 0.77$ & $5.08 \pm 0.43$ \\
\hline$R_{\text {area }}^{\text {ded }}$ & $0.77 \pm 0.28$ & $0.84 \pm 0.10$ & $0.43 \pm 0.06$ & $0.63 \pm 0.02$ & $0.31 \pm 0.07$ & $0.33 \pm 0.09$ \\
\hline gs & $41.7 \pm 22.4$ & $174.3 \pm 21.0$ & $46.5 \pm 11.4$ & $125.4 \pm 54.3$ & $64.1 \pm 16.0$ & $66.8 \pm 5.2$ \\
\hline$A_{\text {mass }}$ & $60.8 \pm 40.9$ & $96.1 \pm 3.1$ & $79.6 \pm 13.0$ & $105.0 \pm 34.4$ & $155.0 \pm 25.0$ & $143.7 \pm 8.8$ \\
\hline$R_{\text {mass }}$ & $11.1 \pm 4.2$ & $10.7 \pm 2.9$ & $6.8 \pm 1.3$ & $9.0 \pm 0.2$ & $11.8 \pm 3.7$ & $9.1 \pm 2.9$ \\
\hline $\mathrm{gs}_{\text {mass }}$ & $0.59 \pm 0.39$ & $1.71 \pm 0.18$ & $0.73 \pm 0.21$ & $1.78 \pm 0.94$ & $1.97 \pm 0.48$ & $1.89 \pm 0.09$ \\
\hline WUE & $68.8 \pm 16.2$ & $60.6 \pm 2.8$ & $105.5 \pm 13.9$ & $69.3 \pm 13.2$ & $78.8 \pm 7.0$ & $78.4 \pm 3.0$ \\
\hline PNUE & $46.22 \pm 25.18$ & $55.08 \pm 9.05$ & $60.35 \pm 5.43$ & $65.66 \pm 17.49$ & $76.17 \pm 10.65$ & $81.93 \pm 6.22$ \\
\hline $\mathrm{Ci} / \mathrm{Ca}$ & $0.64 \pm 0.09$ & $0.62 \pm 0.02$ & $0.46 \pm 0.06$ & $0.60 \pm 0.04$ & $0.59 \pm 0.03$ & $0.59 \pm 0.01$ \\
\hline
\end{tabular}

$\mathrm{HI} \quad \mathrm{MI}$

\begin{tabular}{|c|c|c|c|c|c|c|}
\hline \multirow[b]{2}{*}{ Trait } & & & \\
\hline & LW & HW & LW & $\mathrm{HW}$ & LW & $\mathrm{HW}(n=3)$ \\
\hline \multicolumn{7}{|c|}{ Quercus pyrenaica (deciduous) } \\
\hline \multicolumn{7}{|c|}{ Structural traits } \\
\hline Area & $13.0 \pm 2.2$ & $16.5 \pm 2.4$ & $20.1 \pm 2.2$ & $18.3 \pm 1.8$ & $12.1 \pm 1.5$ & $14.0 \pm 2.5$ \\
\hline SLA & $117.54 \pm 4.69$ & $123.63 \pm 7.04$ & $160.11 \pm 8.96$ & $158.63 \pm 3.10$ & $281.52 \pm 29.14$ & $255.15 \pm 6.29$ \\
\hline $\mathrm{N}_{\text {mass }}$ & $17.75 \pm 1.20$ & $22.54 \pm 0.96$ & $17.71 \pm 0.81$ & $22.85 \pm 1.25$ & $25.95 \pm 2.93$ & $22.92 \pm 0.25$ \\
\hline $\mathrm{C}_{\text {mass }}$ & $429.2 \pm 11.4$ & $439.7 \pm 6.3$ & $433.8 \pm 0.9$ & $437.2 \pm 11.1$ & $438.2 \pm 6.8$ & $440.6 \pm 9.8$ \\
\hline $\mathrm{N}_{\text {area }}$ & $1.52 \pm 0.07$ & $1.85 \pm 0.12$ & $1.10 \pm 0.07$ & $1.44 \pm 0.08$ & $0.92 \pm 0.02$ & $0.92 \pm 0.02$ \\
\hline $\mathrm{C}_{\text {area }}^{\text {ared }}$ & $3.68 \pm 0.19$ & $3.61 \pm 0.20$ & $2.69 \pm 0.17$ & $2.76 \pm 0.03$ & $1.63 \pm 0.14$ & $1.76 \pm 0.10$ \\
\hline Chl index & $19.2 \pm 2.9$ & $24.3 \pm 1.7$ & $23.0 \pm 1.6$ & $31.4 \pm 1.5$ & $29.0 \pm 3.5$ & $25.4 \pm 3.4$ \\
\hline \multicolumn{7}{|c|}{ Physiological traits } \\
\hline$\Phi$ & $0.0372 \pm 0.008$ & $0.0523 \pm 0.0007$ & $0.0310 \pm 0.0047$ & $0.0529 \pm 0.0039$ & $0.0451 \pm 0.0059$ & $0.0643 \pm 0.0092$ \\
\hline$\theta$ & $0.980 \pm 0.011$ & $0.824 \pm 0.057$ & $0.974 \pm 0.023$ & $0.906 \pm 0.026$ & $0.797 \pm 0.097$ & $0.615 \pm 0.069$ \\
\hline LCP & $19.7 \pm 1.9$ & $23.4 \pm 3.6$ & $11.6 \pm 4.3$ & $17.9 \pm 6.7$ & $9.6 \pm 3.1$ & $14.5 \pm 7.0$ \\
\hline LSP & $293.8 \pm 93.3$ & $621.8 \pm 54.7$ & $153.2 \pm 53.2$ & $434.1 \pm 21.8$ & $294.1 \pm 53.7$ & $378.4 \pm 46.6$ \\
\hline$A_{\text {area }}$ & $4.69 \pm 2.04$ & $15.22 \pm 1.27$ & $4.00 \pm 1.35$ & $13.76 \pm 0.22$ & $5.51 \pm 0.62$ & $5.36 \pm 0.80$ \\
\hline $\mathrm{R}_{\text {area }}$ & $0.55 \pm 0.03$ & $1.19 \pm 0.17$ & $0.32 \pm 0.10$ & $0.85 \pm 0.24$ & $0.38 \pm 0.06$ & $0.85 \pm 0.38$ \\
\hline $\begin{array}{l}\text { area } \\
\text { gs }\end{array}$ & $52.7 \pm 29.3$ & $293.9 \pm 10.7$ & $34.6 \pm 18.0$ & $274.8 \pm 33.4$ & $86.1 \pm 7.7$ & $101.2 \pm 11.2$ \\
\hline$A_{\text {mass }}$ & $57.8 \pm 26.8$ & $187.2 \pm 17.8$ & $65.3 \pm 23.8$ & $234.1 \pm 18.2$ & $163.2 \pm 24.8$ & $135.6 \pm 16.6$ \\
\hline$R_{\text {mass }}^{\text {mass }}$ & $6.6 \pm 0.6$ & $14.7 \pm 2.1$ & $5.3 \pm 2.0$ & $14.1 \pm 4.5$ & $11.3 \pm 1.4$ & $22.0 \pm 10.3$ \\
\hline $\begin{array}{l}\text { mass } \\
\text { gs }_{\text {mass }}\end{array}$ & $0.67 \pm 0.40$ & $3.67 \pm 0.34$ & $0.58 \pm 0.32$ & $4.49 \pm 0.44$ & $2.53 \pm 0.35$ & $2.56 \pm 0.23$ \\
\hline WUE & $108.0 \pm 8.6$ & $52.0 \pm 5.0$ & $147.2 \pm 17.7$ & $52.2 \pm 4.7$ & $63.8 \pm 3.8$ & $56.4 \pm 4.8$ \\
\hline PNUE & $43.87 \pm 18.12$ & $115.63 \pm 7.07$ & $61.15 \pm 26.96$ & $143.31 \pm 5.42$ & $87.20 \pm 9.58$ & $87.99 \pm 15.83$ \\
\hline $\mathrm{Ci} / \mathrm{Ca}$ & $0.45 \pm 0.04$ & $0.62 \pm 0.03$ & $0.31 \pm 0.06$ & $0.63 \pm 0.02$ & $0.65 \pm 0.02$ & $0.68 \pm 0.03$ \\
\hline
\end{tabular}

Light treatments: $\mathrm{HI}$, high irradiance, MI, medium irradiance; LI, low irradiance. Water treatments: LW, low water; $\mathrm{HW}$, high water. $\Phi$, Quantum yield (no units); $\theta$, curvature (no units); Area, leaf area $\left(\mathrm{cm}^{2}\right) ; A_{\text {area }}$, photosynthetic rate per area $\left(\mu \mathrm{mol} \mathrm{CO}_{2} \mathrm{~m}^{-2} \mathrm{~s}^{-1}\right) ; A_{\text {mass' }}$ photosynthetic rate per mass $\left(\mathrm{nmol} \mathrm{CO}_{2} \mathrm{~g}^{-1} \mathrm{~s}^{-1}\right) ; \mathrm{C}_{\text {arear }}$ carbon content per area $\left(\mathrm{g} \mathrm{C} \mathrm{m}^{-2}\right) ; \mathrm{C}_{\text {mass' }}$ carbon concentration $\left(\mathrm{mg} \mathrm{g}^{-1}\right) ; \mathrm{Chl}^{\text {index }}$, chlorophyll index (no units); $\mathrm{Ci} / \mathrm{Ca}$, ratio internal vs external $\mathrm{CO}_{2}$ concentration; gs area, stomatal conductance per area $\left(\mathrm{mmol}_{2} \mathrm{H}_{2} \mathrm{O}^{-2} \mathrm{~s}^{-1}\right)$; gs mass' stomatal conductance per mass $\left(\mathrm{mmol} \mathrm{H}_{2} \mathrm{O} \mathrm{g}^{-1} \mathrm{~s}^{-1}\right)$; LCP, light compensation point ( $\mu$ mol photons $\mathrm{m}^{-2} \mathrm{~s}^{-1}$ ); LSP, light saturation point $\left(\mu \mathrm{mol}\right.$ photons $\left.\mathrm{m}^{-2} \mathrm{~s}^{-1}\right) ; \mathrm{N}_{\text {area, }}$, nitrogen content per area $\left(\mathrm{g} \mathrm{N} \mathrm{m}^{-2}\right) ; \mathrm{N}_{\text {mass' }}$, nitrogen concentration $\left(\mathrm{mg} \mathrm{g}^{-1}\right) ; R_{\text {area' }}$, respiration rate per area $(\mu \mathrm{mol}$ $\left.\mathrm{CO}_{2} \mathrm{~m}^{-2} \mathrm{~s}^{-1}\right)$; $\mathrm{R}_{\text {mass }}$ respiration rate per mass $\left(\mathrm{nmol} \mathrm{CO} \mathrm{g}^{-1} \mathrm{~s}^{-1}\right)$; PNUE, photosynthetic nitrogen-use efficiency $\left(\mu \mathrm{mol} \mathrm{CO}_{2}\left(\mathrm{~mol} \mathrm{~N}^{-1} \mathrm{~s}^{-1}\right) ; \mathrm{SLA}_{\text {, }}\right.$ specific leaf area $\left(\mathrm{cm}^{2} \mathrm{~g}^{-1}\right)$; WUE, water-use efficiency $\left(\mu \mathrm{mol} \mathrm{CO} \mathrm{CO}_{2}\left(\mathrm{mmol} \mathrm{H}_{2} \mathrm{O}\right)^{-1}\right)$. 